\title{
Review article: A review and critical analysis of the efforts towards urban flood risk management in the Lagos region of Nigeria
}

\author{
U. C. Nkwunonwo ${ }^{1,2}$, M. Whitworth ${ }^{2}$, and B. Baily ${ }^{3}$ \\ ${ }^{1}$ Department of Geoinformatics and Surveying, University of Nigeria, Enugu Campus, Nigeria \\ ${ }^{2}$ School of Earth and Environmental Sciences, University of Portsmouth, Portsmouth, UK \\ ${ }^{3}$ Department of Geography, University of Portsmouth, Portsmouth, UK \\ Correspondence to: U. C. Nkwunonwo (ugonna.nkwunonwo@port.ac.uk)
}

Received: 28 April 2015 - Published in Nat. Hazards Earth Syst. Sci. Discuss.: 16 June 2015

Revised: 18 January 2016 - Accepted: 22 January 2016 - Published: 5 February 2016

\begin{abstract}
Urban flooding has been and will continue to be a significant problem for many cities across the developed and developing world. Crucial to the amelioration of the effects of these floods is the need to formulate a sound flood management policy, which is driven by knowledge of the frequency and magnitude of impacts of these floods. Within the area of flood research, attempts are being made to gain a better understanding of the causes, impacts, and pattern of urban flooding. According to the United Nations office for disaster reduction (UNISDR), flood risk is conceptualized on the basis of three integral components which are frequently adopted during flood damage estimation. These components are: probability of flood hazard, the level of exposure, and vulnerabilities of elements at risk. Reducing the severity of each of these components is the objective of flood risk management under the UNISDR guideline and idea of "living with floods". On the basis of this framework, the present research reviews flood risk within the Lagos area of Nigeria over the period 1968-2012. During this period, floods have caused harm to millions of people physically, emotionally, and economically. Arguably over this period the efforts of stakeholders to address the challenges appear to have been limited by, amongst other things, a lack of reliable data, a lack of awareness amongst the population affected, and a lack of knowledge of flood risk mitigation. It is the aim of this research to assess the current understanding of flood risk and management in Lagos and to offer recommendations towards future guidance.
\end{abstract}

\section{Introduction}

Flood events and impacts in recent times have arguably been unprecedented and affected the lives of hundreds of millions of people across the world. These impacts have been shared by both developed and developing countries (DCs) with rapid urban expansion taking place in many flood-prone areas. Concerns for flooding and the associated human impacts are clearly of global significance, especially when allied with the fears of climatic change and associated changes in rainfall events and sea level rise (Kundzewicz et al. 2014). The rapidly growing urban environments in many areas correspond with a lack of urban planning strategies, the deterioration and lack of capacity of urban drainage infrastructure and an increased rate of development on floodplains (Gill 2004; CII, 2001). Additionally, the increasing densities of populations (particularly in the urban areas of most DCs such as Nigeria), alongside the poor level of awareness and the limited efforts of many stakeholders towards flood risk reduction are critical issues undermining possible efforts towards addressing the hazard (Action Aid, 2006; McMichael et al., 2006; Raaijmakers et al., 2008). The present research attempts to clarify these issues using a synthesis and analysis of available historical flood data in the Lagos area of Nigeria, spanning the period 1968 to 2012. This research also reviews the current status and awareness of pluvial flood risk within Lagos and makes recommendations to help improve the management of these events. 


\section{Description of the Lagos metropolis of Nigeria}

The Lagos metropolis is a densely populated low-lying coastal area in the southwestern part of Nigeria, West Africa. The city is located within geographical coordinates of 3.1 to $3.4^{\circ} \mathrm{E}$ longitude and 6.5 to $6.8^{\circ} \mathrm{N}$ latitude and covers a land area of approximately $1100 \mathrm{~km}^{2}$ (or $425 \mathrm{sq}$. miles). It is bordered in the south by the Atlantic Ocean (see Fig. 1). With a dense network of roads and buildings, and several inland waterways including the Lagos Lagoon which empties into the Atlantic, the conurbation serves as a major hub for transportation, tourism, and economic activities in Nigeria. With a population of over 20 million people (LSG, 2012), the Lagos metropolis is the biggest city in Nigeria, (although the smallest land area), the second largest city in Africa, and the seventh largest city in the world. The population growth rate in the Lagos metropolis is estimated at 3.2\% (World Bank, 2013). Against this background, the United Nations predicts that Nigeria will be one of the eight countries expected to account collectively for half of the total population increase in the world from 2005 to 2050, and will by 2100, have a population of between 505 million and 1.03 billion (United Nations, 2004). High population density is a major impasse in the Lagos region, subjecting the area to lack of space for the myriad of human activities, which often manifests itself in muddled human settlements, overcrowding, slum envelopments, pollution, illegal structures, and other social and environmental disorder. These factors, either singularly or in combination, have the potential to increase exposure to hazard, especially the risks associated with pluvial urban flooding events.

\section{Flooding in Lagos - frequency, causes, and impacts}

Flooding and flood risk management are issues of grave significance in Lagos (Aderogba, 2012a, b). It is clear from previous studies (for example, Ajibade et al. 2013, 2014; Adelekan, 2013), that flooding in the area can be devastating, affecting hundreds of thousands of people and causing considerable economic damage. A typical example is the July 2011 flooding event, which affected approximately 5 thousand people and resulted in about 25 deaths. The direct economic losses resulting from the event totalled about 50 billion Nigerian naira (i.e. USD 250 million). Public utilities including road networks, bridges, and schools were destroyed. In addition, houses collapsed, private homes were submerged, and several cars were swept away by flood water (IFRC, 2011; Oladunjoye, 2011).

\subsection{Frequency of occurrence}

From a historical perspective, Lagos has always been susceptible to various types of flooding which are well documented from the 1960s onwards (Odunuga, 2008; Oyebande, 1974; Etuonovbe, 2011). However, in recent years pluvial flooding events (rainfall-related), have arguably been more widespread (Olajuyigbe et al., 2012). With the exception of 1973, the drought year, flooding in Lagos has occurred annually (usually between July and October rainy season) with an increasing intensity and an increased severity of impacts from 1960 onwards (Oyebande, 1974). According to FME (2012), Lagos is one of the few locations in Nigeria with more frequent flooding events (see Fig. 2). A number of floods have occurred in the Lagos area, although keeping track of events in the Nigerian context is challenging due partly to lack of relevant data collection capacities. As a result, data relating to hydrodynamics and historical flooding events are often lacking (Ajibade et al., 2013). According to previous studies, more severe flooding has been recorded in select areas of Lagos including Lagos Island, Apapa, Ikeja, Mushin, Surulere, and parts of Ikorodu (Oyebande, 1974; Odunuga, 2008). There is no clear explanation for this peculiar circumstance, but it seems to follow a pattern of spatial and temporal distribution of rainfall within and around Lagos.

Table 1 shows a summary of major flooding events and associated consequences in the Lagos metropolis of Nigeria from 1968 to 2012. These data which appear to represent generalized flooding situations were obtained from a wide range of sources including EM-DAT and the Nigerian FME (Federal Ministry of Environment). It is argued that the conclusions that can be drawn about flooding in Lagos from these data sets relate to events of higher magnitudes and return periods (Guha-Sapir et al., 2013). Only journalistic and non-quantitative evidence is available for lesser impacts and more frequent flooding events (see for example, IFRC, 2012). The problem with these forms of evidence is that they often do not have ethical and empirical groundings. For most of the events considered, data relating to flood duration and impacts in terms of number of people displaced, mortality, and economic losses were not available. On the basis of this inconsistency, the effectiveness of flood management policies is being queried (Adelekan, 2015). In many cases, different types of flood damage were aggregated. Indeed, this situation adversely affects accurate flood damage estimation since a critical understanding of Lagos flood risk in the context of flood damage typology is difficult.

To qualitatively identify risk levels in this area, an approach used in the 2005 World Bank Hotspot project was adopted (Dilley et al., 2005). In this approach, records of flood events and affected areas were coupled with the population density of the local enumeration areas in Lagos and mapped in a GIS. The result of this analysis as shown in Fig. 3, indicates that Ajeromi-Ifelodun and Mushin areas are at a higher risk of flooding than other areas. This approach, regardless of its simplicity, offers a potentially valuable insight into flooding patterns in Lagos. However, much uncertainty lies within the results and this suggests the need for more detailed research that will investigate the flood risk lev- 

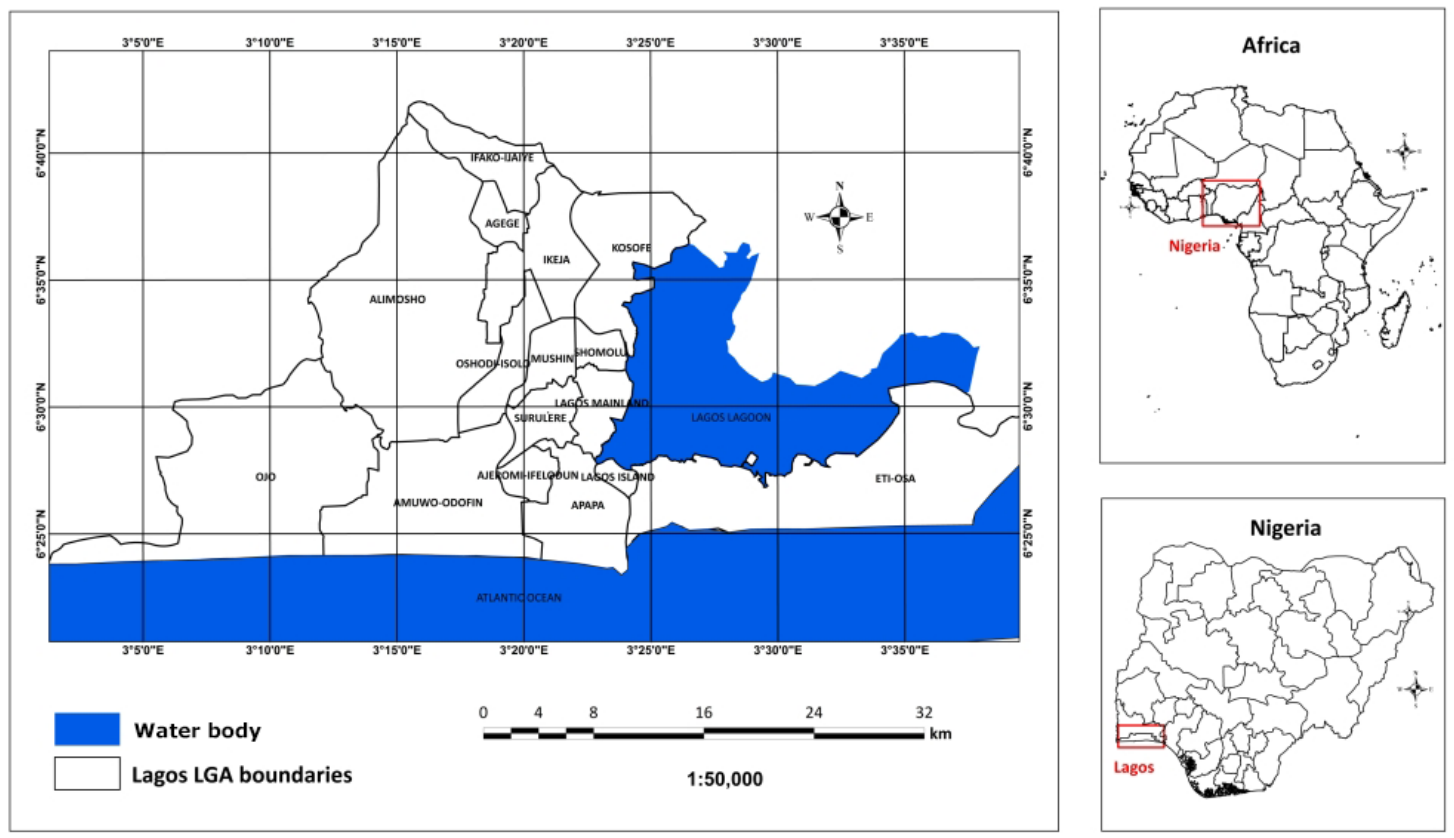

Figure 1. The Lagos metropolis of Nigeria. Inset shows the location of Lagos State in Nigeria.

els at Lagos using a more detailed quantitative or qualitative data set.

\subsection{Causes of flooding}

Over the past 2 decades, the causes of flooding in Lagos have received significant attention in the literature (Ayoade and Akintola, 1980; Action Aid, 2006; Adeloye and Rustum, 2011; Adelekan, 2013; Aderogba, 2012a; Oshodi, 2013; Ajibade et al., 2013, 2014; Soneye, 2014). Debates arising from the literature indicate that Lagos floods are mainly the consequences of climate-change-induced short-durationhigh-intensity or long-duration-low-intensity rainfall (Houston et al., 2011). This is unsurprising considering that climate change has arguably influenced regional precipitation patterns in recent history. Odjugo (2006) concluded that there are now more high-intensity short-duration rainfall events and more low-intensity long-duration rainfall events than there were 3 decades ago. Other factors have also been investigated with reference to the causes of these floods in Lagos. These include the topography of the area, land use (LU) and land cover (LC) modifications, and influence of canals, lagoons, and beaches (Aderogba, 2012a; Aderogba et al., 2012; Odunuga, 2008). Other factors considered are urbanization and population growth, poor urban planning, and poor environmental management and the indiscriminate disposal of solid waste (Lamond et al., 2012; Adeloye and Rustum, 2011). It is also suggested that tidal and co-tidal influences and frequent incursion from the Atlantic into the lowlands during heavy storms also play important roles (Ojinnaka, 2013).
These factors (schematized in Fig. 4), seem to influence the occurrence of the hazard and the exposure of elements at risk. However, in relation to the vulnerabilities of social systems to flooding in the area, the development of slum settlements and poor perception of flooding among local communities, urban residents and the general public are critical factors (Agbola and Agunbiade, 2007; Nkwunonwo, 2013; Ayoade and Akintola, 1980; Odunuga et al., 2012; Oloke et al., 2013; BNRCC, 2008).

\subsection{Impacts of flooding}

To date, flooding in Lagos is characterized by severe consequences, which raise concerns about a lack of early warning and evacuation systems. Impacts from flooding (as illustrated in Fig. 5) are compounded by population density and the upward trends of urban growth in the area (Aderogba, 2012b). Also, flood water depth, inundation extent and duration as well as water flow velocity play contributory roles. The general impacts (such as displacement from homes, mortality, physical injuries, disruption of economic activities, destruction of urban infrastructure, and submergence of buildings) that relate to social systems directly have been extensively considered in the literature (Ugwu and Ugwu, 2013; Adigun et al., 2013; Ajibola et al., 2012; Aderogba, 2012b; Olajuyigbe et al., 2012). However, there are reports that Lagos flooding causes severe additional impacts including the loss of social values, spread of vector-borne diseases, as well as air and water pollution (Adelekan, 2010; Olajuyigbe et al., 2012; Bashir et al., 2012). 

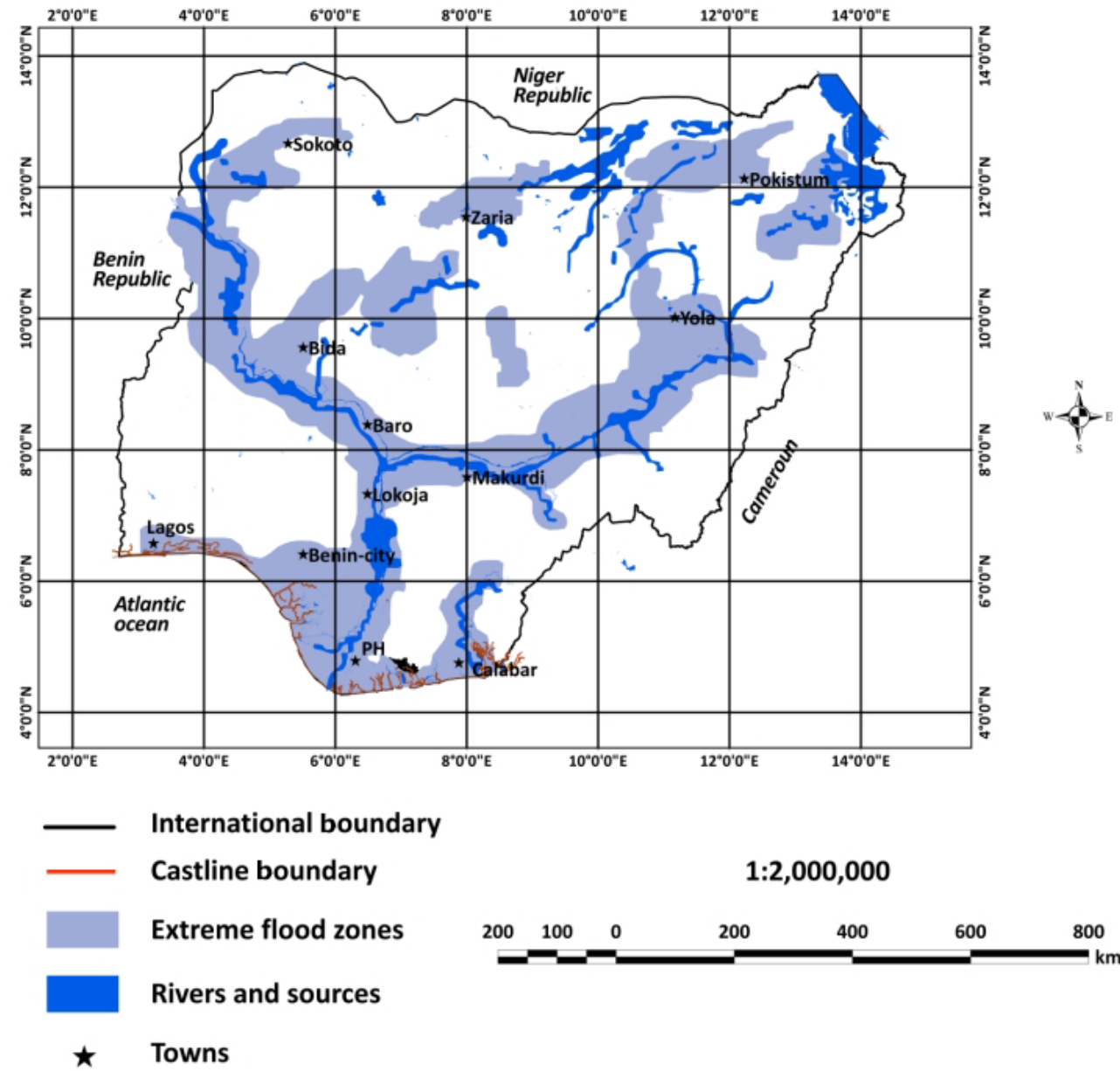

Figure 2. Spatial distribution of areas affected by extreme floods in Nigeria between 2000 and 2012. Adapted from the Federal Ministry of Environment (2012).

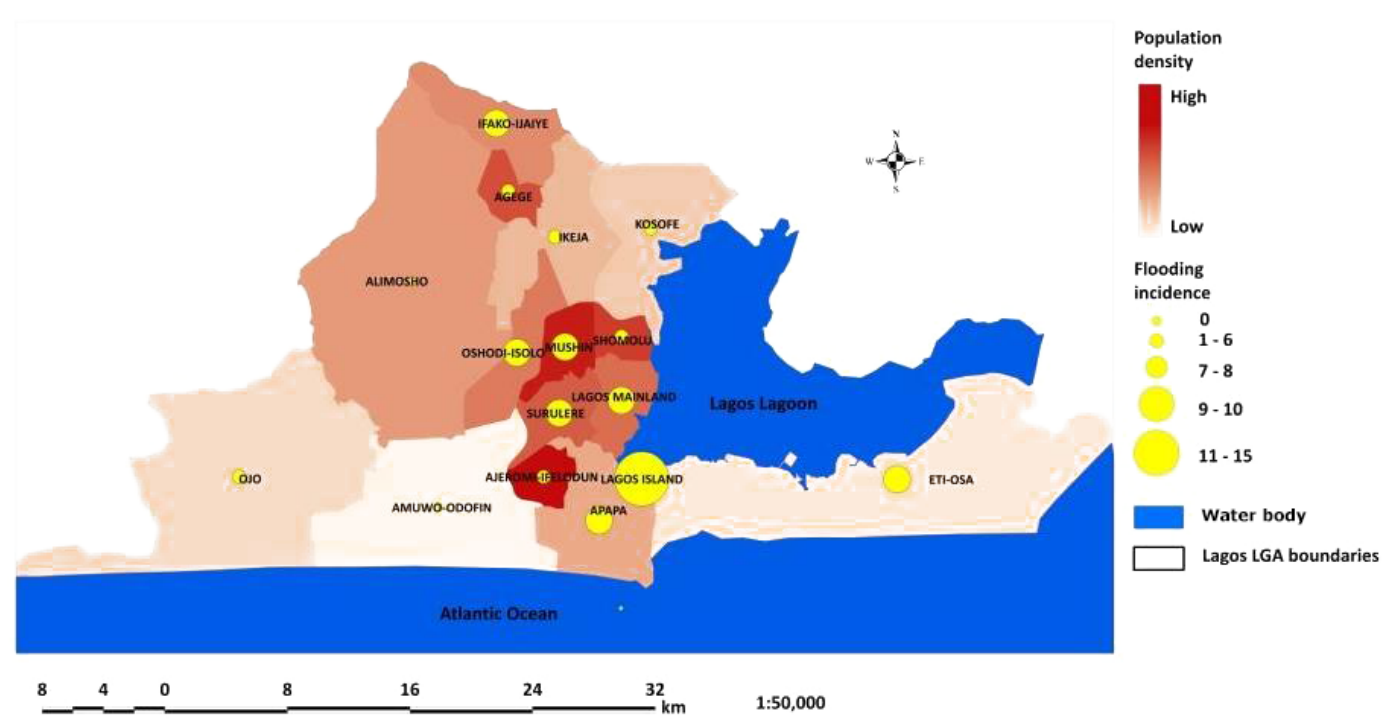

Figure 3. Flood risk levels in the Lagos area qualitatively determined by coupling population density with list of flooding events and locations. 


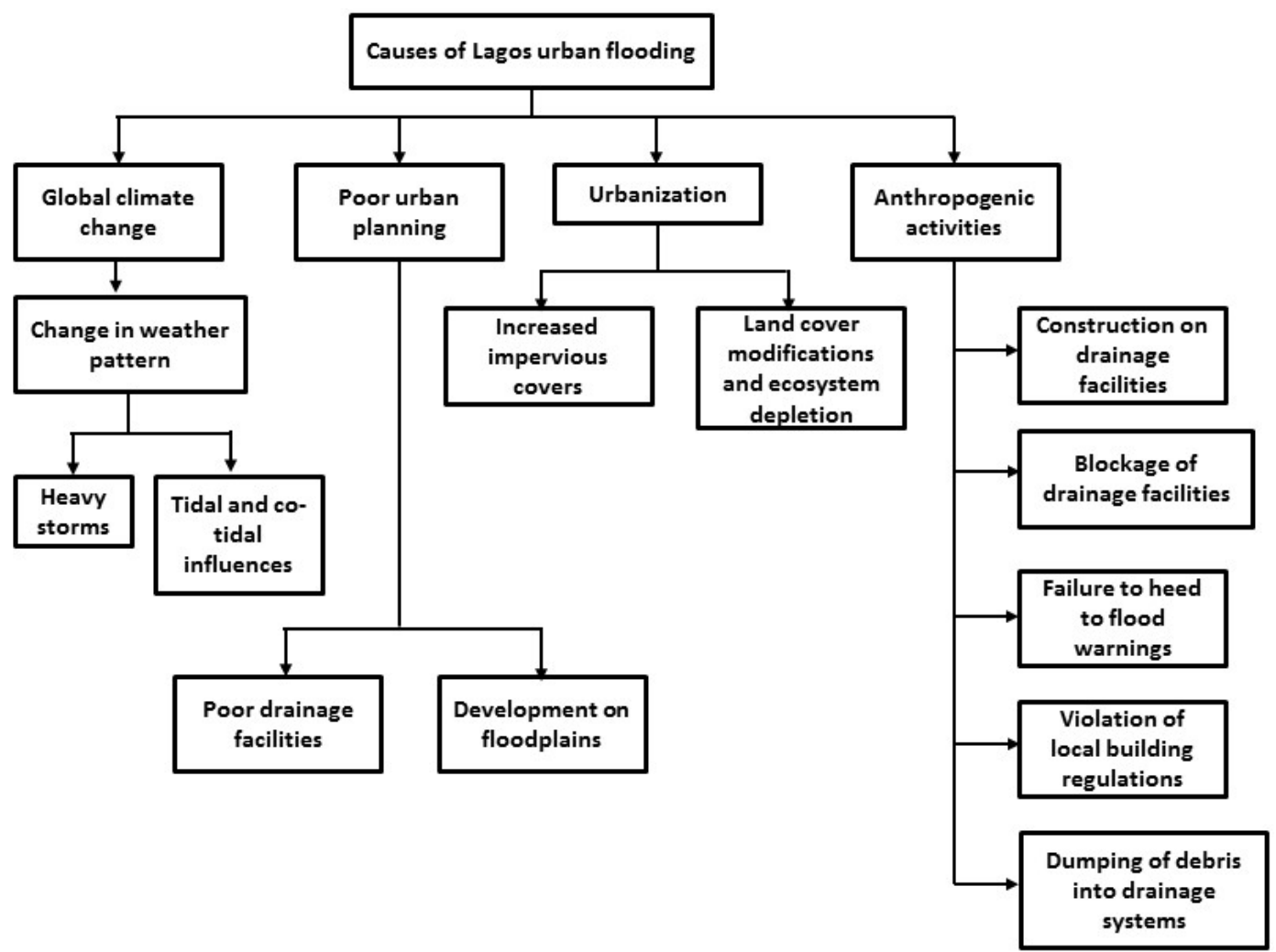

Figure 4. Main causes of urban flooding in the Lagos area of Nigeria showing global climate change, poor urban planning, urbanization, and anthropogenic activities.

Olajuyigbe et al. (2012) report that flood hazard increases city-wide poverty as a result of the farmlands which are destroyed and essential services which are often interrupted. Adelekan (2010) investigated these impacts using four poor urban communities in Lagos as case studies and identified three significant scales: individual, household, and community. At the individual scale, the reluctance of friends and family to visit one another while in flooded houses affects social relationships. This has broad adverse implications on community lifestyle and further compounds depression among flood victims in Lagos. Food insecurity is equally an important issue at this scale as food items stored in individual homes are often lost during flooding. In addition, there can be numerous health impacts including chronic skin infections from exposure to contaminated environmental systems and increased effects on those with an already poor health history.

Household and community scales of impacts are mainly indicated by the secondary effects of flooding in Lagos. Household impacts include deterioration of building quality, intrusion of contaminated water into apartments, lack of good drinking water, and loss or damage to household properties including sanitation facilities. The community impacts include an unclean environment, disruption of movement, and damage to public utilities. Urgent needs arise where community schools were flooded and schooling for children has been interrupted. This is an important issue within the context of human development. In many other DCs where it is also applicable, community leaders and the local authorities have often instigated measures to ensure that children's schooling is not interrupted despite the magnitude of flooding. In Bangladesh for example, a strategy known as "floating schools" in which classrooms are constructed on boats is being put in place during flooding (Huq and Aslam, 2003). This enables provision of uninterrupted education for children who have been impacted and whose education has been disrupted by flood catastrophes.

The impacts of flooding in Lagos also trigger concerns for environmental management, urban sustainability, and the development, governance, and the vulnerability of urban residents and local communities. Other factors of concern are humanitarian needs and services, especially primary health delivery (Soneye, 2014; Ajibade, 2013; Lamond et al., 2012). Needless to say, concerns for solid waste management are crucial as long as the indiscriminate dumping of wastes into drainage systems remains prevalent within Lagos. One example of this is the water sold in polythene sachets which is the major source of drinking water for residents. It is perceived that many residents dispose of the containers which end up in drainage facilities. Being a non-degradable waste, 


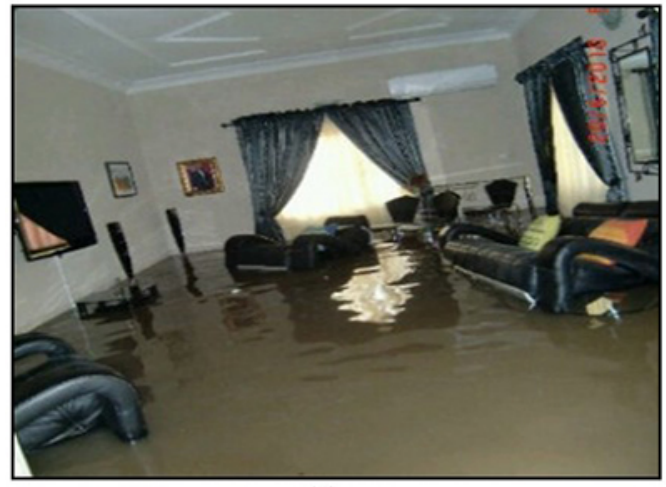

(a)

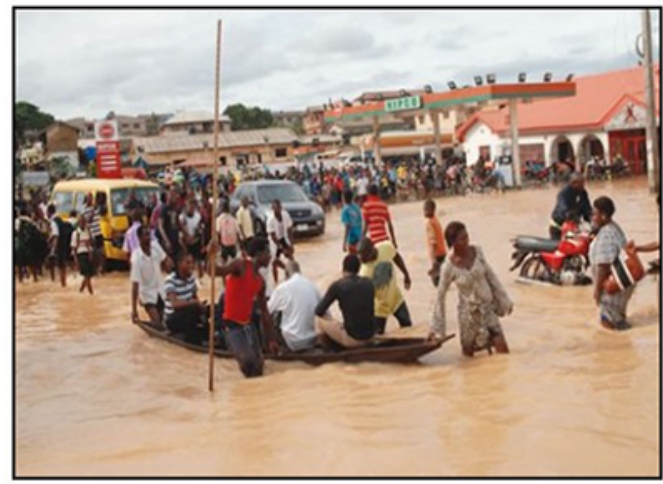

(c)

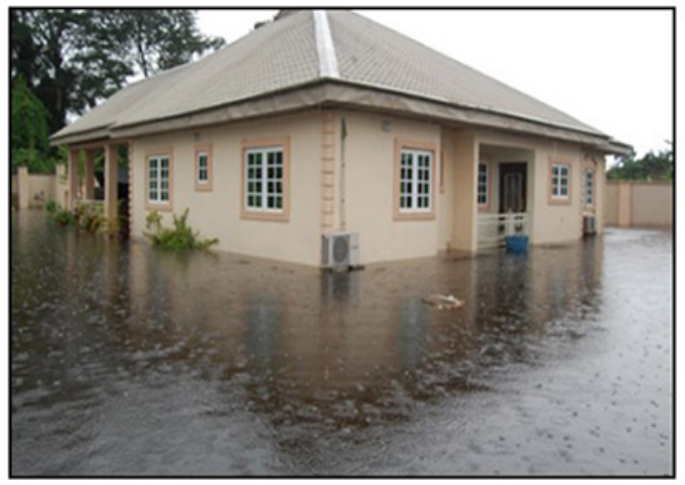

(b)

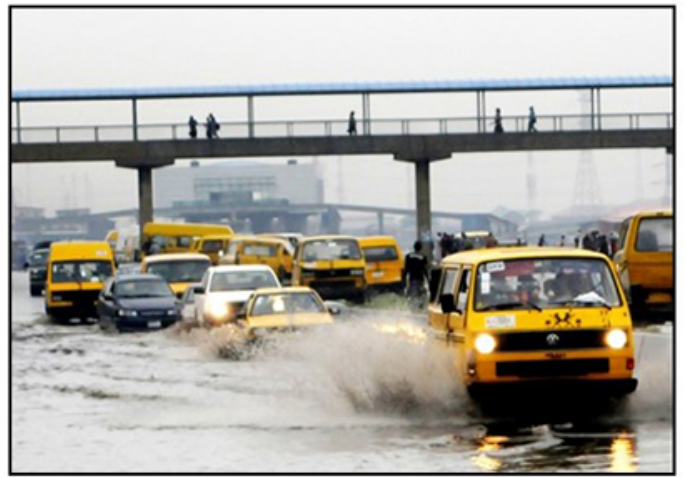

(d)

Figure 5. Some flooding scenes examples in the Lagos metropolis of Nigeria: (a) living room submerged by flood water, (b) residential building submerged, (c) local community affected by flood waters, and (d) expressway overwhelmed by flood water. Source: Online images of flooding in Lagos, Nigeria.

it accumulates over time and blocks these drainage facilities. Unfortunately, little has been done to address such an important issue in flood control management.

\section{Present research and gaps in knowledge}

Despite the frequency of occurrence, causes, and severity of impacts of Lagos urban flooding alongside the understanding of a potentially increased risk in the future a better understanding of flooding in Lagos is lacking. Whilst most of the data relating to these impacts are at local levels and limited to small geographical areas, wide-ranging crossdisciplinary intervention measures are constrained. Lack of data and poor data scale present an important limitation to comprehensive urban flood impact assessment and management. Flood risk management efforts in Lagos considered in the light of global current flood risk management practices (see Sect. 5) reveals significant gaps. A number of nonstructural approaches which promote flood risk assessment and management are frequently ignored. Efforts to manage and assess flood risk in Lagos are aimed at both prevention and control of flooding. Moreover, such efforts have been unprecedented in Nigeria and clearly demonstrate a prac- tical commitment to fighting the flood hazard (Njoku and Udeagha, 2013; Obeta, 2014). However, results from various studies which highlighted the increasing vulnerabilities to flooding indicate that such efforts have so far been of little assistance to the victims of flooding.

The problems of a lack of data and poor data scale in Lagos are exacerbated by the general lack of funds and inadequate access to improved technology alongside a lack of political will (Nkwunonwo et al., 2014; Adeloye and Rustum, 2011). Unfortunately, the level of existing knowledge regarding the state of affairs is unsatisfactory and fails to assist in providing a potential solution to ways of reducing the hazard or its impacts on human populations. The more critical and disturbing scenario is that the Lagos area is a fast-growing city within which a great deal of the population currently lives within areas prone to flooding. Locally, the majority of these areas are slums which provide provisional dwelling places to poor urban residents. Adelekan (2010) argued that these residents often do not have the capacity to cope with flood hazard or the ability to quickly recover from losses. Moreover, the vast spatial distribution of such flood-prone areas in Lagos increases the exposure of the human population to flooding. A clearer picture taken from a global and regional perspective shows that Lagos is among the top 20 cities with 


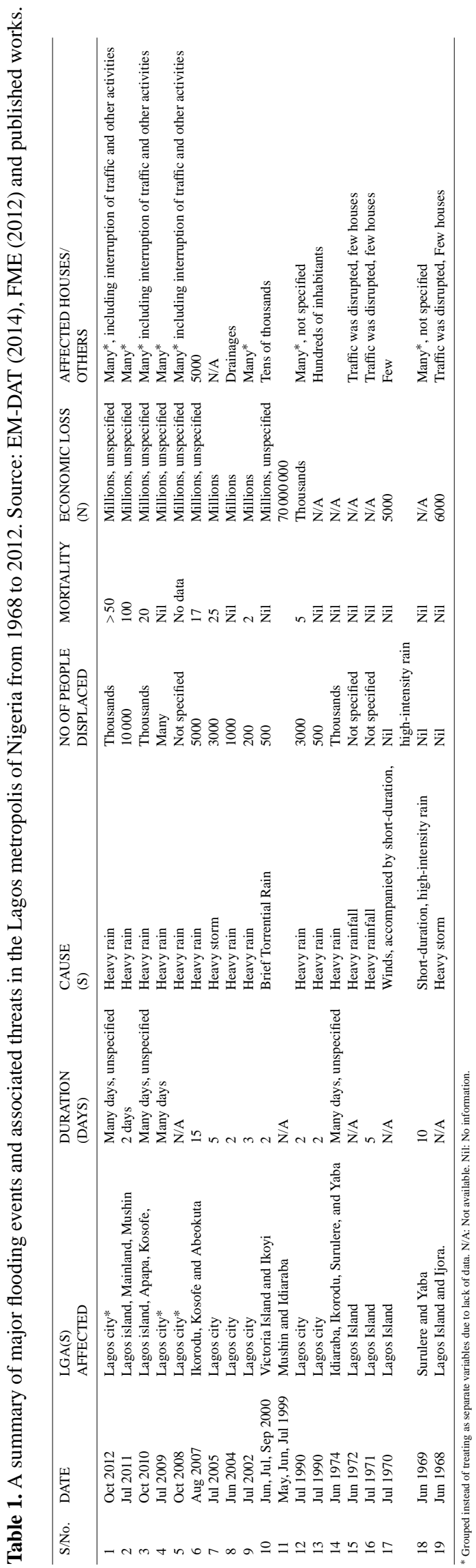

increasing numbers of the present and future population exposed to flooding (see Table 1). Within such an environment, destruction of biodiversity and depletion of ecosystem functions to earn a livelihood are common practices. Given the issues of coping capacity and resilience which remain unresolved for the burgeoning vulnerable population, sustainable development under such circumstances is difficult and almost impossible.

The present research attempts to address the challenges of flooding within and around Lagos through a review of literature and flood information covering the hazard in the area and how it has so far been managed. Available historical flood data in the area, spanning the period 1968 to 2012, were synthesized and analysed. These data were obtained from various online databases (for example: NEST, 1991; Guha-Sapir et al., 2013) and published data on historical flooding in Lagos, Nigeria. Sourcing data from a wide range of databases is an attempt to clarify the issue of lack of flood data which creates significant gaps in knowledge relating to flood management efforts in Lagos. The research discusses the challenges faced by Lagos in managing and reducing flooding impacts. It contextualizes the current situation and puts forward relevant recommendations for more effective remedies to alleviate the threats of flooding in the area. Ultimately, it is argued that the lack of more robust techniques such as flood modelling and assessment of vulnerability accounts for a stark limitation in the efforts towards addressing the challenges of flooding in the area. In particular, the importance of flood modelling in flood risk reduction and the need for it to be included in the present and future efforts at reducing the impacts of flooding are emphasized. This research in general and the recommendations in particular are driven by three key aims: firstly, to understand the unique situation which exists in Lagos in relation to flooding; secondly, to align the focus of flood risk reduction in the Lagos area with that of more developed countries such as the US, the Netherlands, and the United Kingdom; and finally, to suggest measures for possible improvements.

\section{Flood risk management: the general concept}

In recent times, a shift from flood hazard control to flood risk reduction has been found necessary (Samuels et al., 2006). This is due to the inexorable nature of the hazard and the general perception that climate change, demographic, and economic activities would influence regional and global occurrences and consequences of flooding in the future (Kundzewicz et al., 2010, 2014). The importance of this new framework lies in the way in which risk is contextualized, which enables strategic and adaptable policies to be easily formulated.

There are various interpretations of the concept of risk in the literature (see for example Renn, 2008) and this complicates a cross-disciplinary approach to risk reduction. An 
Table 2. Top 20 countries ranked in terms of population exposed to coastal flooding in the 2070s, including both climate change and socioeconomic change and showing present-day exposure. (Source: Nicholls et al., 2008; OECD, Paris.) ( ${ }^{*}$ Highlight of Nigeria is by the authors.)

\begin{tabular}{lllrr}
\hline Rank & Country & $\begin{array}{l}\text { Urban } \\
\text { agglomeration }\end{array}$ & $\begin{array}{r}\text { Exposed population } \\
\text { (current) }\end{array}$ & $\begin{array}{r}\text { Exposed population } \\
\text { (future) }\end{array}$ \\
\hline 1 & India & Calcutta & 1929000 & 14014000 \\
2 & India & Mumbai & 2787000 & 11418000 \\
3 & Bangladesh & Dhaka & 844000 & 11135000 \\
4 & China & Guangzhou & 2718000 & 10333000 \\
5 & Vietnam & Ho Chi Minh City & 1931000 & 9216000 \\
6 & China & Shanghai & 2353000 & 5451000 \\
7 & Thailand & Bangkok & 907000 & 5138000 \\
8 & Myanmar & Rangoon & 510000 & 4965000 \\
9 & USA & Miami & 2003000 & 4795000 \\
10 & Vietnam & Hai Phòng & 794000 & 4711000 \\
11 & Egypt & Alexandria & 1330000 & 4375000 \\
12 & China & Tianjin & 956000 & 3790000 \\
13 & Bangladesh & Khulna & 441000 & 3641000 \\
14 & China & Ningbo & 299000 & 3305000 \\
$15^{*}$ & Nigeria & Lagos & 357000 & $3229000^{*}$ \\
16 & Cote d'ivoire & Abidjan & 519000 & 3110000 \\
17 & USA & New York & 1540000 & 2931000 \\
18 & Bangladesh & Chittagong & 255000 & 2866000 \\
19 & Japan & Tokyo & 1110000 & 2521000 \\
20 & Indonesia & Jakarta & 513000 & 2248000 \\
\hline
\end{tabular}

agreed perception of risk is still lacking despite decades of research. In an attempt to address this conceptual conflict, the United Nations in 1992 proposed a seminal definition: "risk is the expected loss (of lives, persons injured, property damaged, and economic activity disrupted) due to a particular hazard for a given area and reference period". In addition, the United Nations International Strategy for Disaster Reduction defined risk as the combination of probability of a hazard and its negative consequences (UNISDR, 2004). Within these frameworks, hazard-specific and place-based concepts of risk are highlighted (see for example Penning-Rowsell and Chatterton, 1997).

Regardless of conceptual disparity, on the basis of hazard, risk is too often hypothesized as the product of hazard and its consequences (Samuels, 2000; Samuels et al., 2006; De Wrachien et al., 2011; Solín and Skubincan, 2013). This concept of risk generally embodies three components which are considered fundamental to various methods used today in flood risk assessment and management and they include: "probability of hazard occurrence", "exposure", and "vulnerabilities" of elements at risk. Global current flood risk management practices or "best practices" in flood risk management can be identified in a wide range of sources (see for example Ashley et al., 2007; Fratini et al., 2012; Sayers et al., 2013) which aim to reduce the likelihood and/or the consequences of floods. The idea of "living with floods rather than fighting them" is the underlying framework. This philosophy tends towards a policy whereby societies adapt to floods by being prepared and having the right attitude to- wards damage reduction (van Ogtrop et al., 2005). It stems from three key considerations: (1) the limitations or failures of traditional flood control structural measures; (2) the need for a people-friendly means of tackling flooding; and (3) the goal to lessen all impacts of extreme floods while at the same time exploiting all benefits of ordinary floods (UNISDR, 2004; Di Baldassarre and Uhlenbrook, 2012). These considerations are often perceived in the context of a holistic management cycle which covers prevention, protection, preparedness, emergency response, recovery, and lessons learned (Samuels, 2000). Within this framework, a sound understanding of flooding, accurate and actionable assessment of flood hazard and flood risk, knowledge-based decision making, and strong political leadership are indispensable (UNISDR, 2004). As a result, integrated approaches which combine structural and non-structural measures are extensively applied (EC, 2004; Pitt, 2008; Kazmierczak and Carter, 2010; Sayers et al., 2013).

Structural measures which aim at reducing the occurrence of flood hazard are technically based and involve channelization and the use of natural and man-made barriers to contain waters in rivers and seas. Non-structural measures have the aim of reducing vulnerabilities and developing the capacities of ecological systems to cope with floods through multidisciplinary approaches (Few, 2003; Schanze, 2006; Miceli et al., 2008; Sayers et al., 2013). Non-structural measures include flood risk mapping, land use zoning and planning, flood vulnerability assessment, flood proofing, flood modelling, institutionalization of policies, flood awareness cam- 
paign, flood insurance, flood forecasting, relocation of properties, resettlement of human population, and green infrastructure planning (Merz et al., 2007; Jha et al., 2012; Smith, 2013). Fundamental to these measures is the assessment of flood risk which is a procedure to estimate the damage or negative impacts resulting from flooding. Flood negative impacts are often classified in terms of tangible and intangible damage. Tangible damage such as damage to properties and infrastructure are those that can be associated with monetary values. Intangible damage is difficult to express in monetary terms and may include depression, anxiety, and loss of life. Categorization of flooding impacts as direct and indirect damage is also applicable. Direct damage includes those which result from direct contact with flood water. When direct flood damage is tangible, a broader classification, direct tangible flood damage, applies. Indirect tangible flood damage is a secondary consequence of direct flood impacts and may include economic disruption, individual misfortune, and an increase in water-borne diseases (Samuels et al., 2006; Hammond et al., 2015).

The assessment of flood damage on the basis of damage typology is characterized by significant limitations. By means of heterogeneous methodologies, assessment of direct tangible flood damage has received significant attention in the literature (Hammond et al., 2015; Samuels et al., 2006). Damage functions, especially stage-damage curves which have been applied in many case studies around the world, remain potential tools for assessing direct and indirect tangible flood damage (Smith, 1994; Merz et al., 2004). A major limitation of stage-damage curves arises from the neglect of water flow velocity which also influences flood damage. To date, the difficulty in assessing intangible flood damage remains unresolved. Methods are being proposed in the current literature, for example the concept of "anxiety-productivityincome" which assumes that anxiety is a function of flood water depth and duration (Lekuthai and Vongvisessomjai, 2001; Price and Vojinovic, 2008). The "Risk-to-life" model, which uses flood characteristics and an estimate of the number of people exposed to flooding to assess the possible mortality, was proposed by Jonkman et al. (2008). A comprehensive review of other current methods to assess intangible flood losses can be found in Hammond et al. (2015).

Despite the progress made so far, uncertainties and the lack of time series stage data and good-quality damage data are major factors constraining the ubiquitous assessment of flood risk. In line with predictions of worsened future risk scenarios, these constraints underscore the importance of developing capacities for estimating flood hazard (in terms of water depth, velocity, etc.), exposure, and vulnerabilities of elements at risk as discrete components. The review presented in this research considers various aspects of Lagos flood risk assessment and management in light of the general context of flood risk assessment. With regard to flood risk assessment, procedures to estimate flood hazard are reviewed. Fundamental to the research is knowledge about the extent to which current and future ecosystem exposure to flood hazard have been influenced. Given reported trends in urbanization and population growth (summarized in Sect. 8.1), it can be assumed that exposure of systems to flooding in Lagos is at a critical level.

\section{The management and reduction of flood risk in Lagos}

\subsection{General measures}

General measures to tackle the challenges of flooding in Lagos have been discussed by Oshodi (2013). Recent practices have included:

1. The expansion of drainage infrastructure within the city heartland.

2. The annual debris removal from principal drainage facilities within the city heartland.

3. Providing advice to the inhabitants of flood plains and wetlands to relocate.

4. The demolition of homes in flood-prone areas.

5. Proposed resettlement scheme for the residents of Ogun River catchment areas.

Oshodi (2013) claimed that these practices are being carried out, although it could be argued that they are politically influenced. One example of this is the expansion and upgrading of the primary drainage facilities mainly being carried out in Bariga, Surulere, and Gbagada. The annual clearing of primary and secondary channels by Lagos State Government through the Ministry of the Environment is carried out principally in the metropolitan areas. Evacuation and resettlement is carried out for residents who live in flood-prone areas. A proposed resettlement scheme for residents of Ajegunle community near Ikorodu was undertaken between October 2011 and January 2012 (Oshodi, 2013). The move was necessitated based on the belief that the current location of the community in the Lagos urban Master Plan was originally zoned as wetland for agricultural use. The area was a major catchment of Ogun River. It could be argued that the lack of clear implementation policy for the plan with enormous housing shortfall in the city to cope with rapid population growth and urbanization has led to the conversion of the area into residential use. Significant environmental impacts are often associated with the use of land for purposes it was not originally allotted for. Flooding can be the case when such inappropriate use affects ecological equilibrium. However, a sound investigation is needed to validate this claim, especially within the context of Lagos.

Major failures of these general measures arise from the issues of continuity and the scope of application. These measures are often limited to the core urban areas of the city, excluding the majority of the outskirts (Oshodi, 2013). Many 
areas within Lagos did not benefit from the expansion of drainage facilities; moreover, the project was not completed because of a change in administration. These projects often suffer when new governments abandon uncompleted projects of their predecessors. This shows the potential for urban mismanagement and the degree of limitation in urban development given that there are many abandoned projects while new ones are being considered. There are occasional inconsistencies in the annual cleaning of the channels. Sometimes this operation is delayed, which allows debris to accumulate in the channels. Coupled with careless attention to the channels after cleaning, accumulation of debris has led to early collapse of the channels. This causes potholes on motorways and retention surfaces for water during flooding.

The problems of where to relocate to and the sparcity of support for relocation are overwhelming. Given the vast distribution of flood-prone areas and the limited financial resources to facilitate resettlement, the choice of which slum locations to resettle is complicated. Communities which cannot be resettled often face the risk of having individual homes demolished. Examples of this include the Agege and Ijeshatedo demolitions in August 2011 and that of Ijora-Badia in 2010, 2012, and 2013. The demolition of homes is understandably a distressing measure to those affected. It could be argued that a particularly controversial aspect is the failure and neglect of the state government to provide any form of alternative housing arrangements to those whose houses have been demolished. There have been a few exceptional cases, for example the Ijora-Badia (World Bank assisted) drainage channels project, which necessitated the demolition and burning of homes. Following a community-led protest the affected families were awarded relocation assistance costs. On the basis of these potential government inadequacies, Ahonshi (2002), Kamunyori (2007), and Basinsksi (2009), cited in Lawanson (2015), argued that the achievement of government's urban sustainability goals (which include general flood management measures) in Lagos are often without regard to the needs of the poor residents of the area. At the same time, demolition and eviction frequently leads to forced social disconnection amongst families, and compensation and legal process on behalf of those affected can take a significant amount of time to complete. This is in part an aspect of social vulnerability which needs to be investigated within the context of Lagos urban flooding. Under the circumstances of eviction and resettlement uncertainties, most people occupying the flood-prone areas seem to ignore government's flood risk mitigation proposals and flood warnings. This influences large-scale impacts of urban flooding in Lagos. However, despite numerous tensions, this issue has only received limited attention in the literature and in governance.

\subsection{Institutional efforts}

One critical aspect of flood response is the institutional efforts which have been undertaken by local authorities and stakeholders. Odunuga (2008) recognized several flood preventive and curative initiatives ranging from community selfassistance actions to World Bank assisted programmes. Recently, key initiatives, which include the Drain Dock and The Emergency Flood Abatement Gang (EFAG), were launched by the government of Lagos state to improve current efforts towards addressing the challenges of flooding. The ministries of Environment, Works, and Health as well as the Lagos Metropolitan Development and Governance Project (LMDGP) have a number of initiatives aimed at controlling flood hazard in the area, and these include shoreline protection, low carbon emissions, the school advocacy programme, and the climate change club. Lagos is also the first region in Nigeria to carry out a detailed topographic mapping of the area with LiDAR (Light Detection and Ranging) data acquisition and GIS-based analysis aimed at addressing the challenges of flooding. In addition to these efforts, the Nigerian government and international community have been active with measures to address the challenges of flooding at various locations within the country including the Lagos area (Olorunfemi, 2011; NIHSA, 2013). As well as engineering works such as dams, bridges, and sustainable urban drainage systems there has also been financial assistance to victims of flooding and this appears to be a common practice. These are undertaken by the National Emergency Management Agency (NEMA), the Nigeria Hydrological Services Agency (NIHSA), the Nigerian Meteorological Agency (NIMET), and the National Environmental Standards and Regulations Enforcement Agency (NESREA) which in 2009 superseded the Federal Environmental Protection Agency (FEPA). It is not intended to discuss the structure, specific roles, and the unique position of these agencies with regard to flood management in Lagos. These aspects have been comprehensively discussed by Obeta (2014). However, it is important to mention that the activities of these institutions with regards to disaster management are generally coordinated by NEMA.

Although detailed data are not available, a key point will be highlighted in terms of the historical perspective of disaster management institutions, to give clarity to a synthetic description of the temporal evolution of flood awareness in Lagos. The institutional framework in Nigeria can be traced back more than four decades in history. The federal government of Nigeria has since the first, second, and third National Development Plans of 1962-1968, 1970-1974, and 1975-1980 initiated plans for the management of all disasters including flooding. This was organized through the federal and state ministries of works. On the basis of flooding and associated hazards, the primary aim of these initiatives was to create awareness among the citizenry and to develop sound response strategies. This development has evolved to the present time into what is now known as institutional approaches to managing disaster. Lately, the institutional framework has incorporated operations such as flood warning through the NISHA, improving general flood aware- 
ness through the National Orientation Agency (NOA), and integration of local state and federal disaster emergency management agencies.

Despite the recent initiatives, these developments have been criticised as weak, while the roles of the institutions are not clearly defined (Adeaga et al., 2005; Oshodi, 2013; Soneye, 2014; Nkwunonwo et al., 2014; Adelekan, 2015). Critically, current measures undertaken by these agencies appear aimed to control flood rather than mitigate its impacts on ecological systems. Efforts are being made to facilitate evacuation and provide flood victims with urgent humanitarian needs. Environmental sustainability and policy, social responses, physical intervention, and environmental management are also critical issues requiring attention (Aderogba et al., 2012; Olajuyigbe et al., 2012; Aderogba, 2012b; Adeaga, 2008, Ilesanmi, 2010). However, despite the increasing number of people affected, the effectiveness of these efforts is challenged. Whilst it is unreasonable to claim that the weakness of these flood mitigation measures probably leads to more frequent flooding in the area, in can be argued that such measures have improved the experience of the general population with regard to flooding.

\subsection{Recent research efforts}

From the literature, researchers have suggested several options in relation to possible flood hazard mitigation and adaption responses. Adedeji et al. (2012) highlighted the importance of building the capacity for flood preparedness through spatial planning and land management. Ogunsote et al. (2011) suggested combating environmental degradation through sustainable landscaping. The need for sustainable management of solid waste which was emphasized in section 3 of this paper was recommended by Folorunsho and Awosika (2001). Komolafe et al. (2014) argued for the adoption of proactive measures to risk management and adaptation whilst constant geophysical and hydrological evaluation of rising groundwater levels was emphasized by Oyedele et al. (2009). Adelekan (2013) reiterated the UNISDR recommendation which calls for the participation of the private sector in risk management through investment decision making in building and construction. Other factors besides flood prevention are also important to reduce the potential impacts of flood events. The humanitarian relief supply chain for victims of flooding in the Lagos area was investigated by Soneye (2014). This study identified the need for more empirical investigation into such crucial components of flood risk management in Lagos. In relation to the planning framework, sustainable housing development and functionality of planning laws and regulations as well as the role of governance in flood management in the Lagos area and indeed in Nigeria have been examined by a number of authors including Aluko (2011) and Oshodi (2013).

As well as the general discussions in the literature, there is other research which focuses on integral components of flood risk such as probability of flooding, and exposure and vulnerability to flooding. But these are insufficient, and leave significant gaps in knowledge. Insufficient knowledge of the vulnerabilities to flooding of local communities, urban residents, and the general public constrains effective flood risk management in Lagos. Urban flooding in particular has arguably not received the attention it deserves. A general critique, which should provide a nuanced understanding of the strengths and limitations of present efforts to address the threats of flooding in the Lagos area, is lacking. The lack of flood data and other ancillary data, as discussed in Sects. 3 and 5 , is a major setback towards containing these threats and has not been fully addressed. Importantly, the focus of these studies which solely rested on general knowledge of the causes, impacts, and remedies of flooding suggests that the global view of the situation has been imperfect. More scientific approaches such as the flood modelling and flood vulnerability assessment which drives recent approaches to flood risk management in more developed countries are generally lacking. Little action has been undertaken to raise public awareness of flood risk or to address gendered vulnerability, as highlighted by Odunuga et al. (2012), Ajibade et al. (2013), and Adelekan (2010). As an unprecedented measure, the Lagos state government has made significant efforts at providing high-resolution air-borne LiDAR data and topographic maps which promote research towards flood risk in the area. However, since many of these data sets are produced and sold commercially, the limited access of researchers to them arguably undermines their usefulness. A possible solution to such a limited access to LiDAR data is to apply global data sets such as ASTERGDEM (Advanced Spaceborne Thermal Emission and Reflection Radiometer Global Digital Elevation Model) and STRM (Shuttle Radar Topographic Mission). However, the resolution of spatial data is a crucial factor in flood modelling and flood risk assessment. Due to the geomorphology of urban features which significantly influence hydrodynamics, global data sets often do not provide realistic results when used to model flood hazard in urban areas (van de Sande et al., 2012). Flood modelling research is still looking into possible ways of simulating accurate flood variables on the basis of low-scale global data sets.

\section{Flood risk assessment in Lagos}

There has been a great deal of research about the assessment of flood risk in Lagos in general. However, it can be argued that none of these studies explicitly assessed the level of exposure to flooding of social and environmental systems. This aspect of flood risk assessment can be derived from studies that consider LU and LC change analyses, and population expansion and urbanization (see Table 3). From the literature, it is clear that vulnerability is being assessed under varying contexts and objectives. No study known to 
the authors has considered flood hazard estimation, although Odjugo (2006) and Adelekan (2010) investigated rainfall patterns over spatial and temporal scales. Odjugo (2006) investigated the changing rainfall pattern in Lagos over 3 decades. Adelekan (2010) on the basis of qualitative survey and secondary data analyses attributed increasing flood risks in Lagos Island mainly to changes in the frequency and intensity of rainstorms between 1971 and 2005. Other studies that estimate flood hazard were embodied within the general framework of climate change research (see for example Aderogba, 2012a). The lack of an explicit study on flood hazard estimation makes it difficult to appreciate how the probability of flood hazard occurrence is being determined in Lagos. Moreover, a clear understanding of the evolutionary trend of the hazard is denied. A consensus view is that the hazard has been increasing over the last 5 decades (Odunuga, 2008; Adelekan, 2015). It is expected that future research should be directed towards this crucial aspect of flood risk assessment.

\subsection{Exposure}

LU and LC analyses are procedures to classify land use/cover and to identify rates and patterns of change. However, the outcome of these analyses to Lagos has continuously suggested expansion in the urban areas. LU and LC analyses provides a basis for researchers and policy formulators to analyse the current and future urban exposure to environmental hazards especially flooding. Flood risk is heavily influenced by human and economic developments which evolve within spatial and temporal scales (Samuels et al., 2006). These developments are known to influence the hydrological cycle particularly through the development of more impervious surfaces which reduce soil infiltration capacity and lead to increased surface water runoffs. The spatial and temporal dimensions of flood risk can in part be directly related to LU and LC modifications. Barredo and Engelen (2010) and Gupta and Nair (2010) have shown that modelling LU and LC scenarios is integral to flood risk management. Identification of the population and urban growth pattern is also fundamental (Barredo and Demicheli, 2003). Many studies covering this crucial aspect of flood risk assessment within the context of the Lagos area exist in the literature (Table 3). Some of the major conclusions emerging from these studies show that significant sprawl and development in residential and industrial or commercial land classes are progressively taking place. There has been also been increasing pressure on arable lands (Akpomrere and Nyorere, 2012) and depletion of wetlands, mangroves, and swamps are significant issues (Obiefuna et al., 2013). The associated migration of people into Lagos city from other rural communities and states in Nigeria escalates residential needs and challenges. Barredo and Demicheli (2003) predicts that up to 27 million people will inhabit Lagos by 2020. Based on these studies, it can be shown that the level of human and economic resources exposed to urban flooding in Lagos is undoubtedly high. Fig- ure 6 shows the 2012 LU and LC of the Lagos metropolis of Nigeria. Despite this, Lagos is relatively low on a global scale when compared to Calcutta, Dhaka, and Miami (Nicholls et al., 2007). However, the need to identify and address the vulnerabilities of exposed systems should be prioritized.

\subsection{Vulnerability}

There are numerous studies that have considered the vulnerabilities of social and environmental systems to flooding within the Lagos context (for example, Action Aid, 2006; Douglas et al., 2008; Adelekan, 2010; Ajibade et al., 2013, 2014; Nkwunonwo et al., 2015; Nsorfon, 2015; Olokesusi et al., 2015). Action Aid (2006) investigated vulnerability but tied Lagos with five other African cities. The study was carried out on the basis of key management criteria including local people's perceptions of the causes of flooding, adaptation, and the community's social coping capacity. Some of the limitations in the study were addressed by Douglas et al. (2008), who considered the vulnerability on the basis of climate change and adaptation strategies for the urban poor in Africa. Adelekan (2010) investigated the vulnerability of coastal communities in Lagos and responses to changing climatic conditions. The patterns of flood vulnerability and resilience amongst women were investigated by Ajibade et al. (2013). On the basis of political ecology, Ajibade et al. (2014) argued that the two crucial factors responsible for vulnerabilities of social systems in Lagos are limited access to housing and weak housing rights. The sources of social vulnerability to floods in informal settlements of Lagos was investigated in Nsorfon (2015) while Nkwunonwo et al. (2015) highlighted the relevance of assessing such vulnerability for the whole of Lagos. Olokesusi et al. (2015) investigated the influence of awareness of and responses to flood warnings on physical vulnerabilities of the affected communities in Lagos.

Although these studies are major contributions to knowledge which provide some evidence to suggest that vulnerability is an important issue of flood risk in Lagos, significant gaps still exist in the literature with regard to accurate assessment of vulnerability in the area. Most of these studies were based on a limited random sample of data which is insufficient to make accurate generalization. Critical issues of vulnerability analyses such as choice and measurement of vulnerability indices were not addressed. This contradicts a widely accepted philosophy that accurate assessment of vulnerability is related to these critical issues (Adger, 2006). Classical analyses of vulnerability should be able to consider every available factor that undermines the chances of resistance available to social and environmental systems. 


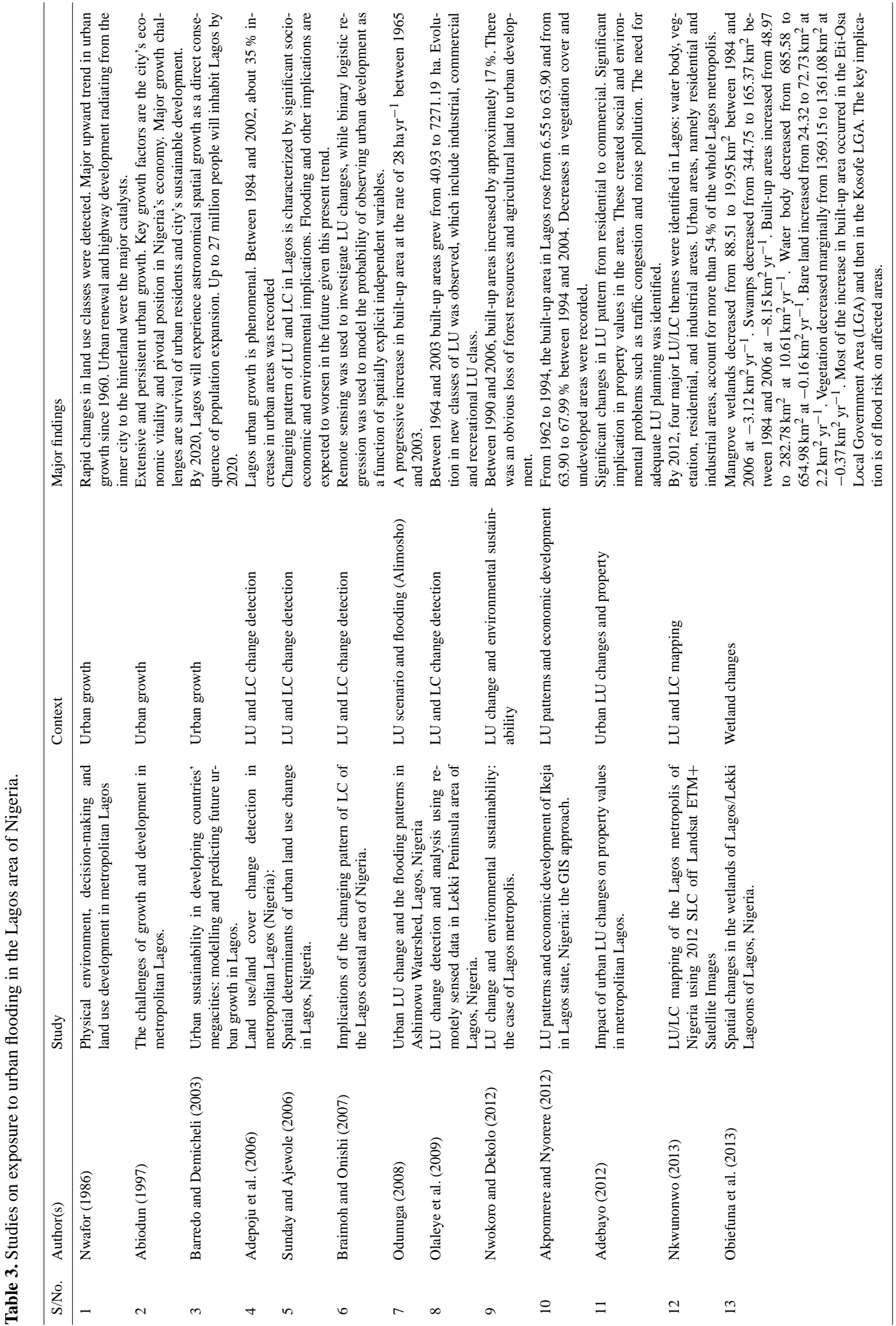




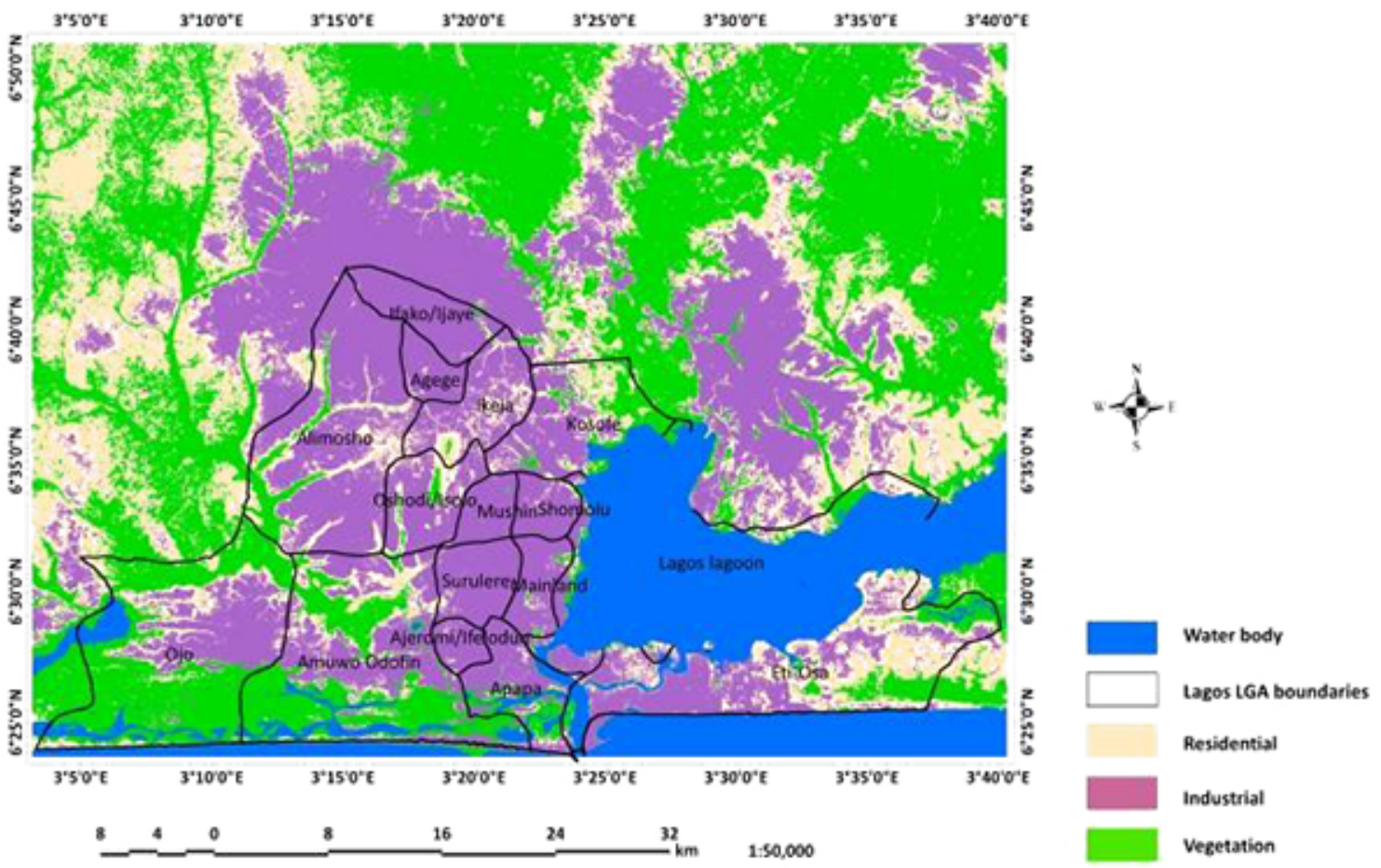

Figure 6. 2012 Land use (LU) and Land Cover (LC) map of the Lagos metropolis of Nigeria. Source: Nkwunonwo (2013).

\section{The case for flood modelling in Lagos}

Based on the issues identified by this research with regard to Lagos, three significant issues emerge which are: (1) lack of data relating to flooding and its consequence, (2) lack of accurate flood risk assessment, and (3) the "unidentifiable method" of flood hazard estimation. To address these issues, flood modelling which is widely being applied in hazard research (see for example Samuels et al., 2006; Merz et al., 2010) to estimate flood hazard should be considered. Attention should be given to the specific objectives that can be achieved in Lagos. It is also important to relate these objectives to specific factors which account for the reasons flood modelling has been largely ignored in the area.

Whilst it is widely acknowledged that stage-damage functions (presented in Sect. 5) are viable tools for flood risk assessment (Samuels et al., 2006; Merz et al., 2010; Hammond et al., 2015), the benefits which Lagos flood risk assessment can derive from such a tool should be investigated. This depends on the availability of various data relating to water depth and extent of flooding events. Even the use of probability concepts to estimate flood hazard requires data relating to a large sample of historical flooding events. As these data are not readily available for Lagos, a flood modelling approach can be used to reconstruct particular historical events (such as 1 in 50, 1 in 100, 1 in 200, 1 in 500, and 1 in 1000 flood return periods) in terms of inundation depth, extent, and water flow velocity, and on the basis of simulated data predict fu- ture occurrences. This will largely improve warning systems currently in place. However, when flooding occurs, and a predicted return period is the case, field survey should be carried out to determine properties and assets that are exposed. If the present market values of the exposed elements are known, damage functions on the basis of ex post flood hazard estimate can be used to assess the level of risk following the flooding event.

Theoretically, flood modelling is a procedure to investigate how rainfall or any other hydrological input into a drainage area is transformed to a streamflow (Chow et al., 1988). Since many of the floods in Lagos are pluvial based, accurate flood modelling results will assist in delineating areas likely to get increased runoff volumes and flooding. Flood modelling will play an important role in producing Lagos flood hazard and flood risk maps which do not currently exist. Needless to say, a comprehensive flood risk and flood hazard map for Lagos will increase public awareness of flood risks and inform stakeholder decision about flood mitigation options and policies in terms of structural and/or non-structural measures. From the point of view of cost benefit analysis (CBA), Lagos area will derive maximum benefits in the long run if flood modelling is the basis of any flood management operation.

Flood modelling is used to promote flood risk reduction in the US, the Netherlands, and the United Kingdom, but in Nigeria it is arguably too often ignored. This has continued to raise the question of how actionable flood risk assessment can be achieved. A number of structural measures are be- 
ing put in place. However, an issue that has been less considered in the Nigerian context is the reliability of structural measures in the absence of accurate flood data and scientific means of acquiring such data. Flood modelling has been largely ignored in Lagos for reasons such as data requirement and availability, lack of specialist technology, funding, and the applied skills required. Academic research seems to be the most likely option in terms of the responsibility to develop flood models. The present research has been unable to refer to specific contributions of academic research towards flood modelling. However, the lack of bespoke or generalized flood models and poor application in flood risk management in the area seem to suggest that flood modelling procedures considered by academic curricula in Lagos are mainly theoretical and on the periphery. As NIHSA (2013) pointed out, such an intensive research should be funded by the government and other interested bodies. To date, the researchers are not aware of any such development. Moreover, the uncertainties associated with flood modelling can discourage investment of resources into it. To the best of the authors' knowledge, no public agency in Lagos undertakes the procedure as a specific role.

It can be argued that relatively few studies have highlighted the relevance of flood modelling and its implications with the paucity of topographic data (Nkwunonwo et al., 2014; van de Sande et al., 2012), although Adeaga (2008) implemented a flood hazard mapping and risk management in the northeastern part of Lagos. Although flood modelling was mentioned in these studies, solutions to the problems raised remain largely unanswered. Critically, current measures undertaken by flood management agencies appear to control flood rather than mitigate its impacts on human populations and urban infrastructure.

\section{Flooding in Lagos - the way forward}

The review of flood management covered in this research prompts several recommendations for reducing flood risk in Lagos. These recommendations are based on three key considerations: first, is the understanding and demonstration of the roles more scientific approaches (such as flood modelling,) can play in flood risk reduction within the context of Lagos; second, is the need to align the focus of flood risk reduction in the Lagos area to the objectives of similar measures in more developed countries such as the US, the UK, and the Netherlands. This should be linked to improving collaboration between Lagos and indeed Nigeria and the developed countries in terms of promoting a more effective flood risk management philosophy. In hazard research, the need for collaboration to strengthen learning and information exchange is increasingly being identified (Thomalla et al., 2006). Moreover, similar to the European Union flood risk directive, regional collaborations are being advocated for countries in Africa (Holloway, 2003). Thirdly, there is a need to promote awareness of flooding among local communities, urban residents and the general public and to delineate more suitable locations for relocation of human populations during flooding events.

Further specific recommendations include:

1. The government of Lagos state should as a matter of urgency prioritize legislation and provision of resources towards flood hazard and flood risk mapping for the whole of Lagos state. This is the basis of flood risk mitigation within the European Union framework, which requires all constituting states to prepare flood hazard and flood risk maps to promote the concept of living with floods (EC, 2004).

2. Flood risk reduction under the "living with floods" idea is multi-disciplinary, indicating that various industries can assist in reducing the impacts of flooding. This is the case in the UK in particular (EA, 2010). In view of the widening of public awareness of flooding, there is a need for improved collaboration between the Lagos state government and federal ministries, departments, and agencies such as NEMA, NESREA, and NIHSA.

3. Flood alert and flood early warning systems should be improved within the Lagos area. Globally, there is a growing concern regarding the dissemination of and response to flood warnings (Moore et al., 2005; Parker et al., 2009). On the basis of this, researchers in the UK and other European countries are anxious that flood warning systems are failing to yield the expected scale of damage savings (Penning-Rowsell et al., 2000; Parker et al., 2009). A review of 20 years of the progress of hazard warning systems in the US was presented by Sorensen (2000) although this research shows that no warning system is perfect for any hazard.

4. A series of issues need to be addressed with regard to the design of flood warning systems, and improved forecasting and response systems which correspond to the needs of the public and are often influenced by social, economic, and environmental variability. These issues should underlie improvements in any flood warning systems in Lagos. The cultural, social, and religious values of the people (which are important to many residents of Lagos) may also need to be taken into consideration when disseminating flood warnings. The reluctance of many people living in flood-prone areas to heed flood warnings should also be thoroughly investigated.

5. Flood insurance is a non-structural approach which many property owners have benefitted from in developed countries following flood disasters. It is argued that the benefits of flood insurance far outweigh the limitations which exist (Treby et al., 2006; Crichton, 2008). Flood insurance is still being applied in places like the 
UK, the Netherlands, and Indonesia, although the coverage is at a relatively low scale (Jha et al., 2012). The need to enable flood victims to recover more quickly underscores flood insurance (Lamond and PenningRowsell, 2014). Purchase of insurance is highly dependent on a number of factors, including its availability and cost, the level of the provision of disaster relief, general risk awareness, and attitudes to collective and individual risk (Lamond et al., 2009). For the Lagos area, poor awareness of flood insurance is a major issue. Urban residents need to know that a means of assisting them recover from flood losses is possible. They must be given the opportunity to try flood insurance based on individual volition. To support the roles of flood insurance in Lagos, it is recommended that the role of FEMA in this regard should be extended to the state, whilst encouraging insurance companies to commence an awareness campaign for property owners to take positive steps towards purchasing insurance cover.

6. The enforcement of environmental standards and laws is often a key factor towards containing adverse effects of climate change including flooding (UN/ISDR, 2004). Indiscriminate waste disposal, construction along the flood plain, and the blockage of drainage facilities, among other anthropogenic activities influence flooding in Lagos and are often illegal. It can be argued that NESREA should embark on enforcement measures to address these issues.

7. The reaction to the 1953 floods in the Netherlands has arguably made the Dutch an exemplar in terms of flood management (Vis et al., 2003). Invariably, the success of flood risk reduction in the Netherlands is built on a strong commitment to avoid a repeat occurrence. The population in general and the Dutch government are committed to the collective efforts which underlie success towards addressing the challenges of flooding. Collective flood management costs each Dutch adult about USD 110 annually (Kazmierczak and Carter, 2010). For this reason, we recommend that urban residents and the general public in Lagos need to engage more fully in flood management and control. This would include raising awareness of the risks and educating the wider public about potential solutions. This would include encouraging adherence to environmental laws and a commitment to engage with flood alerts and early warning systems. To support this, more education is required to make the public more aware about flooding and its consequences. Qualitative research such as CBA, involving the local community should also be encouraged.

8. Globally, it appears that research is proportional to success towards addressing the threats of flooding. From scoping investigations it is clear that literature relating to flooding in Lagos appears embryonic compared to literature in the US, the Netherlands, China, and the UK for example. This is a strong indicator that more research is required for Lagos. Equally, the universities and research agencies should be encouraged to include flood awareness and management in their curricula and programmes. More research should be directed towards developing bespoke hydrologic and hydraulic flood models for simulating flood hazard and other hydrological parameters in the area.

9. Globally, accurate data play a key role in flood risk mitigation and the government of Lagos state has made an unprecedented attempt to improve its data by the acquisition of LiDAR data sets, although access to these data sets has been limited due to funds. Given the importance of these data sets and the need to optimize their usefulness for the Lagos area, the state government should consider subsidizing these data sets for universities and research institutions. Additionally, we also recommend further improvement on data acquisition such as SAR (Synthetic Aperture Radar) for flood modelling within the Lagos area. It is argued that the key to wider applied research requires easy access to data and a collaborative approach between researchers and government agencies.

\section{Conclusion}

Flooding is a global phenomenon, but the impacts in many urban areas in the developing countries can be overwhelming. It is easier to understand the threats of flooding in Lagos by the attention generated both in the media and in academic literature relating to social and environmental science. Flood waters have impacted upon the local population, destroyed critical infrastructure, and disrupted economic activities. However, based on "current practice" in flood management and flood risk reduction in the context of "living with floods", the actions of the state government and other stakeholders towards addressing the challenge of flooding in the Lagos area have arguably been limited. Unfortunately, relevant data on flood events are not readily available and the means of building a community resilient to flood threats have continued to elude present efforts.

This research is an attempt towards addressing the challenges of flooding in and around Lagos. Looking to the future, this research argues that flood modelling and assessment of vulnerability are necessary requisites for more effective results towards addressing the challenges of flooding in the Lagos area and indeed in Nigeria. The wider availability of high-quality data sets (including surface modelling and detailed demographic data) is a crucial step towards addressing this problem. It is recognized that a major limitation of this study and many other studies is the level of information available with regard to flooding in the Lagos area. The majority of the research offers a generalized overview 
of flooding rather than scaling the hazard to the local level. If flood data had been available for LGAs, it would have offered a better understanding of the spatial distribution of flooding over the epoch considered. In addition, there are places within various LGAs which may never have flooded over the period considered. It is important to investigate these locations with a view to finding out how they defend themselves from flooding. It was not intended within this study to address flood modelling and vulnerability assessment. However, the authors recommend future research that focuses on developing bespoke flood models for simulating flood hazard in the Lagos area of Nigeria.

Flooding is and will continue to be a hazard for the people of Lagos. The key to ameliorating the effects of flooding on the population is a more integrated, informed flood management philosophy which is linked to improved data collection and provision. This alongside greater public engagement and education as well as improved government coordination will greatly reduce the potential impacts of flood events on the population of Lagos.

Author contributions. This work was carried out in collaboration between all authors. Nkwunonwo Ugonna designed the study, performed the statistical analysis, managed literature searches, wrote the protocol, and wrote the first draft of the paper. Malcolm Whitworth and Brian Baily reviewed the first draft and made academic contributions. All authors read and approved the final paper.

Acknowledgements. This publication derives from a $\mathrm{PhD}$ research which is being funded by the Tertiary Institutions Education Trust Fund (TETFund) programme for staff of university of Nigeria. The Surveyors Council of Nigeria (SURCON) is acknowledged for providing some emergency grants. Data relating to flooding were sourced mainly from the Center for Research in Epidemiology of Disasters (CRED), Nigeria's Ministry of the Environment and the Nigeria Environmental Study Action/Team (NEST). Previous works in this area are equally acknowledged and so are the anonymous reviewers of this paper.

Edited by: P. Tarolli

Reviewed by: three anonymous referees

\section{References}

Abiodun, J. O.: The challenges of growth and development in metropolitan Lagos. The urban challenge in Africa: growth and management of its large cities, 192-222, 1997.

Action Aid: Climate Change, Urban Flooding and the Rights of the Urban Poor in Africa: Key Findings From Six African Cities, Action Aid International, London, 2006.

Adeaga, O.: Flood Hazard Mapping and Risk Management in Parts of Lagos N. E., available at: http://www.gsdi.org/gsdiconf/ gsdi10/papers/TS13.3paper.pdf (last access: 10 March 2015), 2008.
Adeaga, O., Savic, D. A., Bertoni, J. C., Mariño, M. A., and Savenije, H. H. G.: A sustainable flood management plan for the Lagos environs, in: Sustainable Water Management Solutions for Large Cities: The Proceedings of the International Symposium on Sustainable Water Management for Large Cities (S2): Held During the Seventh Scientific Assembly of the International Association of Hydrological Sciences (IAHS) at Foz Do Iguaçu, Brazil, 3-9 April 2005, No. 293, International Assn of Hydrological Sciences, 226-229, 2005.

Adebayo, M. A.: Impact of urban land use changes on property values in Metropolitan Lagos, The Social Sciences, 4, 111-117, 2009.

Adedeji, O. H., Odufuwa, B. O., and Adebayo, O. H.: Building capabilities for flood disaster and hazard preparedness and risk reduction in Nigeria: need for spatial planning and land management, Journal of Sustainable Development in Africa, 14, 45-58, 2012.

Adeloye, A. J. and Rustum, R.: Lagos (Nigeria) flooding and influence of urban planning, Urban Design and Planning, 164, 175187, 2011.

Adelekan, I.: Vulnerability of poor urban coastal communities to flooding in Lagos, Nigeria, Environ. Urban., 22, 433-450, 2010.

Adelekan, I. O.: Flood risk management in the coastal city of Lagos, Nigeria, Journal of Flood Risk Management, doi:10.1111/jfr3.12179, 2015.

Adelekan, I.: Private Sector Investment Decision in Building and Construction: Increasing, Managing and Transferring Risks: Case Study of Lagos, Nigeria, The United Nations Office for Disaster Risk Reduction, Global Assessment Report on Disaster Risk Reduction, 1-9, 2013.

Adepoju, M. O., Millington, A. C., and Tansey, K. T.: Land use/land cover change detection in metropolitan Lagos (Nigeria): 19842002, ASPRS 2006 Annual Conference Reno, Nevada May, 1-5, 2006.

Aderogba, K.: Qualitative studies of recent flood and sustainable growth and development of cities and towns in Nigeria, International Journal of Academic Research in Economics and Management Science, 1, 1-25, 2012a.

Aderogba, K.: Global warming and challenges of floods in Lagos metropolis, Nigeria, Academic Research International, 2, 448468, 2012b.

Aderogba, K., Martins, O. M., Oderinde, S., and Afelumo, T.: Challenges of poor drainage systems and floods in Lagos metropolis, Nigeria, International Journal of Social Science and Education, 2, 412-427, 2012.

Adger, W. N.: Vulnerability, Global Environ. Chang., 16, 268-281, 2006.

Adigun, F., Abolade, O., and Yusuf, A. A.: Incidence of flood and its impacts: empirical evidence from Ajeromi-Ifeledun, Lagos State, Nigeria, International Journal of Innovative Research and Studies, 2, 239-254, 2013.

Agbola, T. and Agunbiade, E.: Urbanization, slum development and security of tenure: the challenges of meeting millennium development goal (MDG 7) in metropolitan Lagos, Nigeria, in: PRIPODE Workshop, Nairobi, Kenya, 11-13 June 2007.

Ahonsi, B. A.: Popular shaping of metropolitan forms and processes in Nigeria: glimpses and interpretations from an informed Lagosian, in: Documenta11_Platform4, edited by: Enwezor, O., Basualdo, C., Bauer, U. M., Leifeld, B., Ghez, S., Maharaj, S., 
Nash, M., Zaya, O., Müller, M., and Nollert, A., Under Siege: Four African Cities, , Freetown, Johannesburg, Kinshasa, Lagos and Ostfildern-Ruit, Hatje Cantz, 129-151, 2002.

Ajibade, I., McBean, G., and Bezner-Kerr, R.: Urban flooding in Lagos, Nigeria: patterns of vulnerability and resilience among women, Global Environ. Change, 23, 1714-1725, 2013.

Ajibade, I., Armah, F. A., Kuuire, V. Z., Luginaah, I., McBean, G., and Tenkorang, E. Y.: Assessing the bio-psychosocial correlates of flood impacts in coastal areas of Lagos, Nigeria, J. Environ. Plann. Man., 58, 445-463, doi:10.1080/09640568.2013.861811, 2014.

Ajibola, M. O., Izunwanne, E. M., and Ogungbemi, A. O.: Assessing the effects of flooding on residential property values In Lekki Phase I, Lagos, Nigeria, International Journal of Asian Social Science, 2, 271-282, 2012.

Akpomrere, O. R. and Nyorere, O.: Land Use Patterns and Economic Development of Ikeja in Lagos State, Nigeria: The Geographic Information System Approach, International Journal of Economic Development Research and Investment, 3, 39-47, 2012.

Aluko, O.: Sustainable housing development and functionality of planning laws in Nigeria: the case of cosmopolitan Lagos, Journal of Sustainable Development, 4, 139-150, 2011.

Ashley, R., Garvin, S., Pasche, E., Vassilopoulos, A., and Zevenbergen, C. (Eds.): Advances in urban flood management, CRC Press, London, UK, 2007.

Ayoade, J. O. and Akintola, F. O.: Public perception of flood hazard in two Nigerian cities, Environ. Int., 4, 277-280, 1980.

Bashir, O., Oludare, H., Johnson, O., and Aloysius, B.: Floods of fury in Nigerian cities, Journal of Sustainable Development, 5, 69-79, 2012.

Basinkski, S.: All Fingers Are Not Equal: A Report on Street Vendors in Lagos, Nigeria. Lagos: CLEEN Foundation, avialable at: http://www.cleen.org/allfingersarenotequalreport.pdf (last access: 10 March 2015). 2009.

Barredo, J. I. and Demicheli, L.: Urban sustainability in developing countries' megacities: modelling and predicting future urban growth in Lagos, Cities, 20, 297-310, 2003.

Barredo, J. I. and Engelen, G.: Land use scenario modeling for flood risk mitigation, Sustainability, 2, 1327-1344, 2010.

Braimoh, A. K. and Onishi, T.: Spatial determinants of urban land use change in Lagos, Nigeria, Land Use Policy, 24, 502-515, 2007.

BNRCC (Building Nigeria's Response to Climate Change): Vulnerability, Impacts and Adaptation, Climate Change in Nigeria, available at: www.infoo@ climatechange.org (last access: 10 March 2015), 2008.

Chow, V. T., Maidment, D. R., and Mays, L. W.: Applied Hydrology, McGraw-Hill, Amsterdam, the Netherlands, 1988.

CII (Climate Change and Insurance): Chartered Institute for Insurance, Research report of the Chartered Institute for Insurance, London, 2001.

Crichton, D.: Role of insurance in reducing flood risk, Geneva Pap. R. I.-Iss. P., 33, 117-132, 2008.

De Wrachien, D., Mambretti, S., and Schultz, B.: Flood management and risk assessment in flood-prone areas: Measures and solutions, Irrig. Drain., 60, 229-240, 2011.
Di Baldassarre, G. and Uhlenbrook, S.: Is the current flood of data enough? A treatise on research needs for the improvement of flood modelling, Hydrol. Process., 26, 153-158, 2012.

Dilley, M., Chen, R. S., Deichmann, U., Lerner-Lam, A., Arnold, M., Agwe, J., Buys, P., Kjekstad, O., Lyon, B., and Yetman, G.: Natural Disaster Hotspots, A Global Risk Analysis, Washington, D.C., The World Bank, 2005.

Douglas, I., Alam, K., Maghenda, M., Mcdonnell, Y., McLean, L., and Campbell, J.: Unjust waters: climate change, flooding and the urban poor in Africa, Environ. Urban., 20, 187-205, 2008.

EA (Environment Agency): Working With Natural Processes to Manage Flood and Coastal Erosion Risk, Environment Agency, London, 2010.

EC (European Commission): Flood Risk Management - Flood Prevention, Protection and Mitigation, Communication From the Commission to the Council, the European Parliament, the European Economic and Social Committee and the Committee of the Regions, Brussels, 2004.

EM-DAT: The International Disaster Database - Centre for Research on the Epidemiology of Disasters - CRED: Flooding Data for Nigeria, available at: www.emdat.be/ (last access: 10 March 2015), 2014.

Etuonovbe, A. K.: The devastating effect of flooding in Nigeria, in: FIG Working Week, May 2011, available at: http://www.fig. net/pub/fig2011/papers/ts06j/ts06j_etuonovbe_5002.pdf (last access: March 2015), 2011.

Few, R.: Flooding, vulnerability and coping strategies: local responses to a global threat, Progress in Development Studies, 3, 43-58, 2003.

FME (Federal Ministry of Environment): Bulletin on Ecological Disasters, FME, Abuja, Nigeria, 25, 2012.

Folorunsho, R. and Awosika, L.: Flood Mitigation in Lagos, Nigeria through Wise Management of Solid Waste: a case of Ikoyi and Victoria Islands, Nigerian, UNESCO-CSI workshop, 19-23 November 2001, Maputo, 2001.

Fratini, C. F., Geldof, G. D., Kluck, J., and Mikkelsen, P. S.: Three Points Approach (3PA) for urban flood risk management: A tool to support climate change adaptation through transdisciplinarity and multifunctionality, Urban Water J., 9, 317-331, 2012.

Gill, S.: Literature Review: Impacts of Climate Change on Urban Environments - Draft 30 Copy, with contributions from: Pauleit, S., Ennos, R., Lindley, S., Handley, J., Gwilliam, J., and Ueberjahn-Tritta, A., The Impact of Flooding on Urban and Rural Communities, Centre for Urban and Regional Ecology, University of Manchester, UK, 2004.

Guha-Sapir, D., Hoyois, P., and Below, R.: Annual Disaster Statistical Review 2012: The Numbers and Trends, CRED, Brussels, 2013.

Gupta, A. K. and Nair, S. S.: Flood risk and context of land-uses: Chennai city case, Journal of Geography and Regional Planning, 3, 365-372, 2010.

Hammond, M. J., Chen, A. S., Djordjević, S., Butler, D., and Mark, O.: Urban flood impact assessment: A state-of-the-art review, Urban Water J., 12, 14-29, 2015.

Holloway, A.: Disaster risk reduction in Southern Africa: hot rhetoric-cold reality, African Security Studies, 12, 29-38, 2003.

Houston, D., Werritty, A., Bassett, D., Geddes, A., Hoolachan, A., and McMillan, M.: Pluvial (Rain-Related) Flooding in Urban Ar- 
eas: the Invincible Hazard, Joseph Rowntree Foundation, York, UK, 2011.

Huq, S. and Alam, M.: Flood management and vulnerability of Dhaka City. Building Safer Cities: The Future of Disaster Risk, Washington, D.C., 121-135, 2003.

IFRC (International Federation of Red Cross and Red Crescent): Nigeria: Floods - July, available at: http://reliefweb.int/disaster/ fl-2012-000138-nga (last access: 10 March 2015), 2012.

Ilesanmi, A. O.: Urban sustainability in the context of Lagos megacity, Journal of Geography and Regional Planning, 3, 240-252, 2010.

Isong, M., Eyo, E., Eyoh, A., Nwanekezie, O., Olayinka, D. N., Udoudo, D. O., and Ofem, B.: GIS cellular automata using artificial neural network for land use change simulation of Lagos, Nigeria, Journal of Geography and Geology, 4, p. 94, 2012.

Jha, A. K., Bloch, R., and Lamond, J.: Cities and flooding: a guide to integrated urban flood risk management for the 21st century, World Bank Publications, Washington, D.C., 2012.

Jonkman, S. N., Vrijling, J. K., and Vrouwenvelder, A.: Methods for the estimation of loss of life due to floods: a literature review and a proposal for a new method, Nat. Hazards, 46, 353-389, 2008.

Kamunyori, S.: A growing space for dialogue: the case of street vending in Nairobi's Central business district, Unpublished MCP thesis, Massachusetts Institute of Technology, Boston, MA, 2007.

Kazmierczak, A. and Carter, J.: Adaptation to Climate Change Using Green and Blue Infrastructure, a Database of Case Studies, GRaBS project, University of Manchester, Manchester, UK, 2010.

Komolafe, A. A., Adegboyega, S. A. A., Anifowose, A. Y., Akinluyi, F. O., and Awoniran, D. R.: Air pollution and climate change in Lagos, Nigeria: needs for proactive approaches to risk management and adaptation, American Journal of Environmental Sciences, 10, 412-423, 2014.

Kundzewicz, Z. W., Hirabayashi, Y., and Kanae, S.: River floods in the changing climate - observations and projections, Water Resour. Manag., 24, 2633-2646, 2010.

Kundzewicz, Z. W., Kanae, S., Seneviratne, S. I., Handmer, J., Nicholls, N., Peduzzi, P., Mechler, R., Bouwer, L.M., Arnell, N., Mach, K., Muir-Wood, R., Brakenridge, G. R., Kron, W., Benito, G., Honda, Y., Takahashi, K., and Sherstyukov, B.: Flood risk and climate change: global and regional perspectives, Hydrolog. Sci. J., 59, 1-28, 2014.

Lagos State Government (LSG): Abstract of Local Government Statistics, Lagos: Lagos Bureau of Statistics, Ministry of Economic Planning and Budget Secretariat, Alausa, Ikeja, 2012.

Lamond, J. and Penning-Rowsell, E.: The robustness of flood insurance regimes given changing risk resulting from climate change, Climate Risk Management, 2, 1-10, 2014.

Lamond, J., Bhattacharya, N., and Bloch, R.: The role of solid waste management as a response to urban flood risk in developing countries, a case study analysis, in: Flood Recovery Innovation and Response, edited by: Proverbs, D., Mambretti, S., Brebbia, C., and de Wrachien, D., WIT Press, Southampton, 193-205, 2012.

Lamond, J. E., Proverbs, D. G., and Hammond, F. N.: Accessibility of flood risk insurance in the UK: confusion, competition and complacency, J. Risk Res., 12, 825-841, 2009.
Lawanson, T.: Potentials of the urban poor in shaping a sustainable Lagos metropolis, in: Untamed Urbanism, edited by: Allen, A., Lampis, A.,and Swilling, M., Routledge, New York, 108-118, 2015.

Lekuthai, A. and Vongvisessomjai, S.: Intangible flood damage quantification, Water Resour. Manag., 15, 343-362, 2001.

McMichael, A. J., Woodru, R. E., and Hales, S.: Climate change and human health: present and future risks, Lancet, 367, 859869, 2006.

Merz, B., Kreibich, H., Thieken, A., and Schmidtke, R.: Estimation uncertainty of direct monetary flood damage to buildings. Natural Hazards and Earth System Sciences, 4,153-163, 2004.

Merz, B., Thieken, A. H., and Gocht, M.: Flood risk mapping at the local scale: concepts and challenges, in: Flood risk management in Europe, Springer, the Netherlands, 231-251, 2007.

Merz, B., Kreibich, H., Schwarze, R., and Thieken, A.: Review article "Assessment of economic flood damage", Nat. Hazards Earth Syst. Sci., 10, 1697-1724, doi:10.5194/nhess-10-16972010, 2010.

Miceli, R., Sotgiu, I., and Settanni, M.: Disaster preparedness and perception of flood risk: A study in an alpine valley in Italy, J. Environ. Psychol., 28, 164-173, 2008.

Moore, R. J., Bell, V. A., and Jones, D. A.: Forecasting for flood warning, C. R. Geosci., 337, 203-217, 2005.

NEST (Nigeria Environmental Study/Action Team): Nigeria's Threatened Environment: a National Profile, Ibadan, Nigeria: NEST, IRC Main, Abuja, Nigeria, 824 NG91, 9582, 1991.

Nicholls, R., Hanson, J. S., Herweijer, C., Patmore, N., Hallegatte, S., Corfee-Morlot, J., Château, J., and Muir-Wood, R.: Ranking of Port Cities With High Exposure and Vulnerabilities to Climate Extremes, OECD Environment Working Papers, No. 1, OECD Publishers, University of Southampton, UK, 2008.

NIHSA (Nigeria Hydrological Services Agency): Flood Outlook, available at: http://nahs.org.ng/wp-content/uploads/2014/ 10/Nigeria-Flood-Outlook-for-2014.pdf (last access: 10 March 2015), 2013.

NIMET: 5 Nigerian Meteorological Agency: NIMET Weather Data Pack-1, available at: http://nimet.gov.ng/content/ nimet-weather-data-pack-1 (last access: 10 March 2015), 2012.

Njoku, J. D. and Udeagha, M.: Assessing the flooding potentials of Oguta Lake Watershed using remote sensing technology, Paper presented at 5th Annual National Conference, Abuja, organized by the Nigerian Association of Hydrological Sciences (NAHS) at University of Nigeria, Nsukka, 21-30, 2013.

Nkwunonwo, U. C.: Land use/land cover mapping of the Lagos metropolis of Nigeria using 2012 SLC-off Landsat ETM+ Satellite Images, International Journal of Scientific and Engineering Research, 4, 1217-1223, 2013.

Nkwunonwo, U. C., Whitworth, M., Baily, B., and Inkpen, R.: The development of a simplified model for urban flood risk mitigation in developing countries, in: Vulnerability, Uncertainty, and Risk Quantification, Mitigation, and Management, ASCE, USA, 1116-1127, 2014.

Nkwunonwo, U. C., Whitworth, M., and Baily, B.: Relevance of social vulnerability assessment to flood risk reduction in the Lagos metropolis of Nigeria, British Journal of Applied Science \& Technology, 8, 366-382, 2015. 
Nsorfon, I. F.: Exploring Social Vulnerability to Natural Disasters in Urban Informal Settlements-Perspectives from Flooding in the Slums of Lagos, Nigeria, Doctoral dissertation, Universität zu Köln, Köln, 2015.

Nwafor, J. C.: Physical environment, decision-making and land use development in Metropolitan Lagos, GeoJournal, 12, 433-442, 1986.

Nwokoro, I. I. C. and Dekolo, S. O.: Land use change and environmental sustainability: The case of Lagos Metropolis, The Sustainable City VII: Urban Regeneration and Sustainability, 1, 157-167. 2012.

Obeta, C. M.: Institutional approach to flood disaster management in Nigeria: need for a preparedness plan, British Journal of Applied Science \& Technology, 4, 4575-4590, 2014.

Obiefuna, J. N., Nwilo, P. C., Atagbaza, A. O., and Okolie, C. J.: Spatial changes in the wetlands of Lagos/Lekki Lagoons of Lagos, Nigeria, Journal of Sustainable Development, 6, p. 123, 2013.

Odjugo, P. A. O.: An analysis of rainfall pattern in Nigeria, Global Journal of Environmental Sciences, 4, 139-145, 2006.

Odunuga, S.: Urban Land Use Change and the Flooding in Ashimowu Watershed, Lagos, 20 Nigeria, $\mathrm{PhD}$ thesis, University of Lagos, Nigeria, 2008.

Odunuga, S., Oyebande, L., and Omojola, A. S.: Social-economic indicators and public perception on urban flooding in Lagos, Hydrology for Disaster Management: Special Publication of the Nigerian Association of Hydrological Sciences, NAHS, Abuja, 82-96, 2012.

Ogunsote, O. O., Adedeji, Y. M. D., and Prucnal-Ogunsote, B.: Combating environmental degradation through sustainable landscaping in emerging mega cities: a case study of Lagos, Nigeria, in: Proceedings of the 24th World Congress of Architecture "UIA2011 TOKYO", 25 September to 1 October, Tokyo, Japan, 16-21, 2011.

Ojinnaka, O.: Hydrography in Nigeria and Research Challenges, FIG Working Week 2013, Environment for Sustainability, TS05E - Hydrographic Education and Standards - 6439 (1-11), Abuja, available at: http://www.fig.net/pub/fig2013/papers/ts05e/ TS05E_ojinnaka_6439.pdf (last access: 10 March 2015), 2013.

Oladunjoye, M.: Nigeria: July 10 Flooding - Lagos Gives Relief Materials to Victims, Daily Champion Newspaper, available at: http://allafrica.com/stories/201109080792.html (last access: 8 February 2015), 2011.

Olajuyigbe, A. E., Rotowa, O. O., and Durojaye, E.: An assessment of flood hazard in Nigeria: the case of mile 12, Lagos, Mediterranean Journal of Social Sciences, 3, 367-375, 2012.

Olaleye, J. B. and Abiodun, O. E.: Land Use Change Detection and Analysis Using Remotely Sensed Data in Lekki Peninsula Area of Lagos, Nigeria, Eliat Isreal: FIG Working Week, 1-15, 2009.

Oloke, O. C., Ijasan, K. C., Ogunde, A. O., Amusan, L. M., and Tunji-Olayeni, P. F.: Improving urban residents' awareness of the impact of household activities on climate change in Lagos State, Nigeria, Journal of Sustainable Development, 6, 56-64, 2013.

Olokesusi, F., Olorunfemi, F. B., Onwuemele, A., and Oke, M. O.: Awareness of and responses to the 2011 flood warnings among vulnerable communities in Lagos, Nigeria, in: Global Sustainability, Springer International Publishing, Switzerland, 203-223, 2015.
Olorunfemi, F. B.: Managing flood disasters under a changing climate: lessons from Nigeria and South Africa, Paper presented at NISER Research Seminar Series, NISER, Ibadan, 3 May 2011, $1-44,2011$.

Oshodi, L.: Flood management and governance structure in Lagos, Nigeria, Regions Magazine, 292, 22-24, 2013.

Oyebande, L.: Drainage protection to urban lands: an environmental challenge, Nigerian Geographical Association Conference, 1621 December 1974, University of Nigeria, Nsukka, Enugu, 1-7, 1974.

Oyedele, K. F., Ayolabi, E. A., Adeoti, L., and Adegbola, R. B.: Geophysical and hydrogeological evaluation of rising groundwater level in the coastal areas of Lagos, Nigeria, B. Eng. Geol. Environ., 68, 137-143, 2009.

Parker, D. J., Priest, S. J., and Tapsell, S. M. Understanding and enhancing the public's behavioural response to flood warning information, Meteorol. Appl., 16, 103-114, 2009.

Penning-Rowsell, E. C. and Chatterton, J. B.: The Benefits of Flood Alleviation: A Manual of Assessment Techniques, Gower Publishing Company Limited, Aldershot, UK, 1977.

Penning-Rowsell, E. C., Tunstall, S. M., Tapsell, S. M., and Parker, D. J.: The benefits of flood warnings: real but elusive, and politically significant, Water Environ. J., 14, 7-14, 2000.

Pitt, M.: Lessons from the 2007 Floods, Pitt Review, London, 2008.

Price, R. K., and Vojinovic, Z.: Urban flood disaster management, Urban Water J., 5, 259-276, 2008.

Raaijmakers, R., Krywkow, J., and van der Veen, A.: Flood risk perceptions and spatial multicriteria analysis: an exploratory research for hazard mitigation, Nat. Hazards, 46, 307-322, 2008.

Renn, O.: Concepts of Risk: An Interdisciplinary Review Part 1: Disciplinary Risk Concepts, GAIA, 17, 50-66, 2008.

Samuels, P., Klijn, F., and Dijkman, J.: An analysis of the current practice of policies on river flood risk management in different countries, Irrig. Drain., 55, S141-S150, 2006.

Samuels, P. G.: An overview of flood estimation and flood prevention. In invited paper presented at the first international symposium on flood defense, Kassel Reports of Hydraulic Engineering, 9, G1-G11, 2000.

Sayers, P., Li, Y., Galloway, G., Penning-Rowsell, E., Shen, F., Wen, K., Chen, Y., and Le Quesne, T.: Flood Risk Management: a Strategic Approach, UNESCO, Paris, 2013.

Sayers, P. B., Hall, J.W., and Meadowcroft, I. C.: Towards riskbased flood hazard management 25 in the UK, Proceedings of ICE Civil Engineering, 150, 1 May 2002, 36-42, 2002.

Schanze, J.: Flood risk management - a basic framework. In Flood risk management: Hazards, vulnerability and mitigation measures, Springer, the Netherlands, 1-20, 2006.

Smith, K.: Environmental hazards: assessing risk and reducing disaster, Routledge, London, 2013.

Smith, D. I.: Flood damage estimation - a review of urban stagedamage curves and loss functions, Water SA, 20, 231-238, 1994.

Solín, L'. and Skubincan, P.: Flood risk assessment and management: review of concepts, definitions and methods, Geogr. J., 65, 23-44, 2013.

Soneye, A.: An overview of humanitarian relief supply chains for victims of perennial flood disasters in Lagos, Nigeria (20102012), Journal of Humanitarian Logistics and Supply Chain Management, 4, 179-197, 2014. 
Sorensen, J. H.: Hazard warning systems: Review of 20 years of progress, Natural Hazards Review, 1, 119-125, 2000.

Sunday, O. A. and Ajewole, A. I.: Implications of the changing pattern of land cover of the Lagos Coastal Area of Nigeria, American-Eurasian Journal of Scientific Research, 1, 31-37, 2006.

Thomalla, F., Downing, T., Spanger-Siegfried, E., Han, G., and Rockström, J.: Reducing hazard vulnerability: towards a common approach between disaster risk reduction and climate adaptation, Disasters, 30, 39-48, 2006.

Treby, E. J., Clark, M. J., and Priest, S. J.: Confronting flood risk: implications for insurance and risk transfer. J. Environ. Manage., 81, 351-359, 2006.

Ugwu, L. I. and Ugwu, D. I.: Gender, floods and mental health: the way forward, International Journal of Asian Social Science, 3, 1030-1042, 2013.

UN (United Nations): World Population to 2300, United Nations Department of Economic and Social Affairs, Population Division, New York, 2004.
UN/ISDR: United Nations International Strategy for Disaster Reduction: Living with Risks: a global Review of Disaster Reduction Initiatives, 2004 Version Volume 1, available at: http:// www.unisdr.org/files/657_lwr1.pdf (last access: 10 March 2015), 2004.

van de Sande, B., Joost, L., and Hoyng, C.: Sensitivity of coastal flood risk assessments to digital elevation models, Water, 4, 568579, 2012.

van Ogtrop, F. F., Hoekstra, A. Y., and van der Meulen, F.: Flood management in the lower Incomati River Basin, Mozambique: two alternatives, J. Am Water Resour. As., 41, 607-619, 2005.

Vis, M., Klijn, F., De Bruijn, K. M., and Van Buuren, M.: Resilience strategies for flood risk management in the Netherlands, International Journal of River Basin Management, 1, 33-39, 2003.

World Bank: World Bank Population Growth Rate 2009-2013, available at: http://data.worldbank.org/indicator/SP.POP.GROW (last access: 10 March 2015), 2013. 